Selected Papers from the 2nd International Radiocarbon and Diet Conference: Aquatic Food Resources and Reservoir Effects, 20-23 June 2017, Aarhus, Denmark

(C) 2018 by the Arizona Board of Regents on behalf of the University of Arizona. This is an Open Access article, distributed under the terms of the Creative Commons Attribution-NonCommercial-NoDerivatives licence (http://creativecommons.org/licenses/by-nc-nd/4.0/), which permits non-commercial re-use distribution, and reproduction in any medium, provided the original work is unaltered and is properly cited. The written permission of Cambridge University Press must be obtained for commercial re-use or in order to create a derivative work

\title{
CONSIDERATION OF FRESHWATER AND MULTIPLE MARINE RESERVOIR EFFECTS: DATING OF INDIVIDUALS WITH MIXED DIETS FROM NORTHERN SWEDEN
}

Jack P R Dury ${ }^{1,3^{*}} \cdot$ Gunilla Eriksson $^{1} \cdot$ Markus Fjellström $^{1} \bullet$ Thomas Wallerström $^{2} \bullet$ Kerstin Lidén ${ }^{1}$

\footnotetext{
${ }^{1}$ The Archaeological Research Laboratory, Department of Archaeology and Classical Studies, Stockholm University, Wallenberglaboratoriet, SE-10691 Stockholm, Sweden.

${ }^{2}$ Department of Historical Studies, Norwegian University of Science and Technology (NTNU), NO-7491 Trondheim, Norway.

${ }^{3}$ Arctic Centre, University of Groningen, Aweg 30, NL-9718 CW Groningen, The Netherlands.
}

\begin{abstract}
Human burials from the cemetery at the Rounala church, northern Sweden, were radiocarbon $\left({ }^{14} \mathrm{C}\right)$ dated to shed light on the use of the cemetery. Carbon, nitrogen and sulfur stable isotope analysis of bone collagen from 19 distinct individuals indicated that these individuals had a mixed diet consisting of freshwater, marine and terrestrial resources. Dietary modeling using FRUITS was employed to calculate the contributions of the different resources for each individual. These data were then used to calculate individual $\Delta \mathrm{R}$ values, taking into account freshwater and multiple marine reservoir effects, the latter caused by Baltic and Atlantic marine dietary inputs, respectively. ${ }^{14} \mathrm{C}$ dating of tissues from modern freshwater fish species demonstrate a lack of a freshwater reservoir effect in the area. Two OxCal models were used to provide endpoint age estimates. The calibrated data suggest that the site's cemetery was most likely in use already from the 14th century, and perhaps until at least the late 18 th century.
\end{abstract}

KEYWORDS: bone collagen, northern sweden, reservoir effects, Sámi, stable isotopes.

\section{INTRODUCTION}

The cemetery of Rounala is associated with the historical Rounala church (Figure 1). Situated alongside one of the main trade routes between the Gulf of Bothnia and the Norwegian Sea (Hoppe 1945:69), it is thought that the church at Rounala was the first church to be built in the Torne lappmark, northern Sweden. Based on historical records, Wiklund (1916:10) suggests that the church at Rounala was built in the 1500s, most likely after 1559, when a missionary was sent by King Gustav Vasa to proselytize among the Sámi in that region. The history of Sámi religious practices is complex, with periods of both Swedish and Norwegian Christianization (Aronsson 2013; Kent 2014; Rasmussen 2016). As this building was the first known church in the Torne lappmark, it could aid in our understanding of how and when Christianity was spread into this area. According to a written account, the church was abandoned in 1643, at the latest-or possibly already in 1606, as dictated by a royal decree (Wallerström 2017). The church no longer stands today as it fell into disrepair after its abandonment and its material remains were sold and moved to another site during the late 18th century (Wiklund 1916:12). However, during its use as a church, several people were buried at the cemetery.

During the excavation in 1915 by Eskil Olsson, the remains of 23 distinct humans were identified (Wiklund 1916:17-19). According to Manker (1961:96), the burial styles are somewhat diverse, probably reflecting a mix of Sámi and Christian traditions, as recently discussed by historian Siv Rasmussen (2016). The possibility that the graveyard was in use prior to the founding of the church must not be disregarded. Here we aim to date the burial events of the interred individuals so as to understand the relationship between the graveyard and the church; did the burials begin before the church's construction?

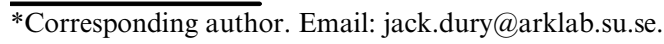




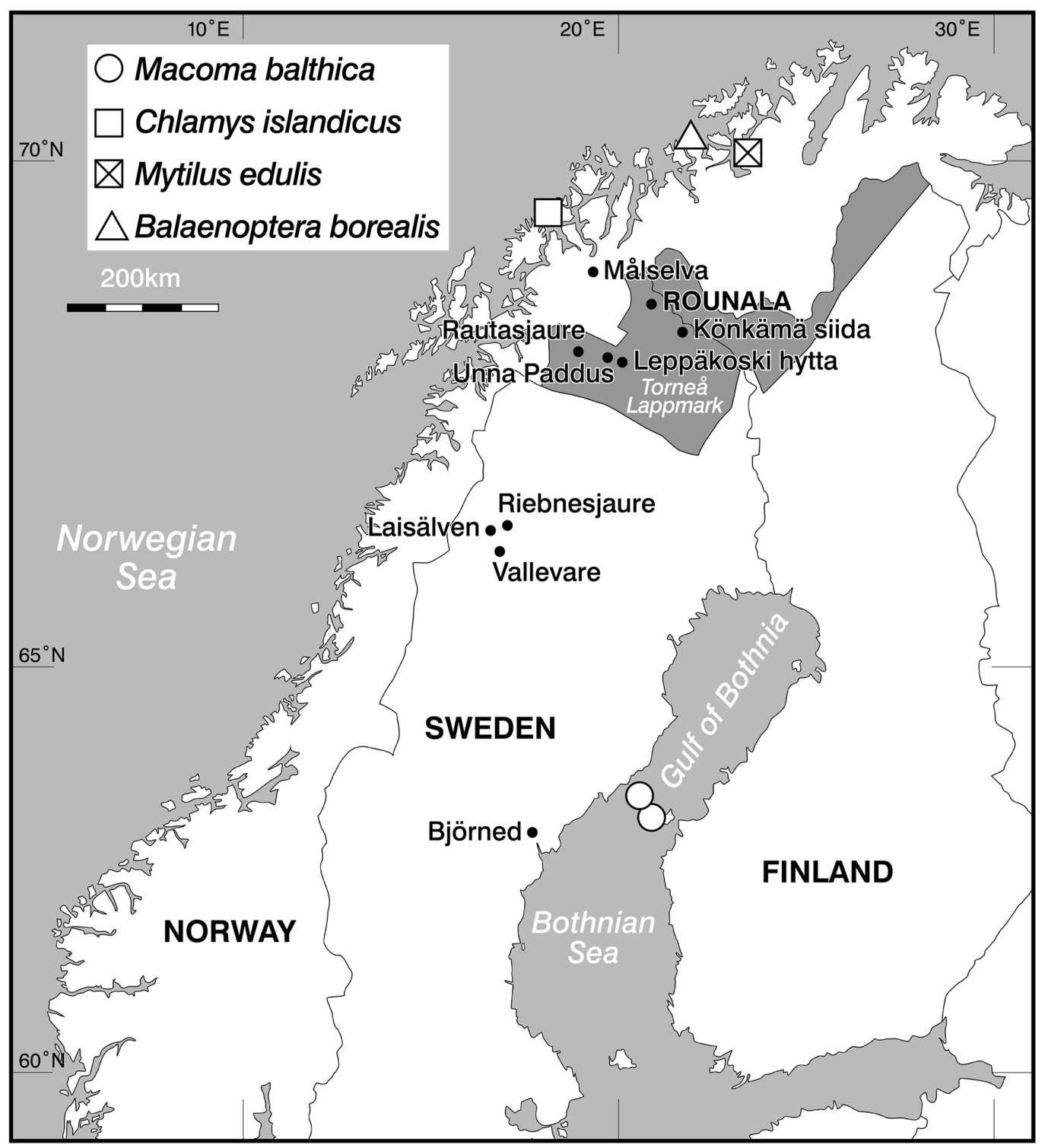

Figure 1 Map of northern Fennoscandia showing the location of Rounala, the lake of Riebnesjaure, rivers of Målselva and Laisälven, the location of the reindeer samples, and the locations of the marine species used to calculate marine $\Delta \mathrm{R}$ values. The shaded area denotes Torne lappmark (see main text).

A careful calibration of the individuals' radiocarbon $\left({ }^{14} \mathrm{C}\right)$ dates will be necessary to establish the time of burial. This calibration must be made with regard to reservoir effects potentially influencing these samples. Marine and freshwater reservoir effects occur due to the accumulation of ${ }^{14} \mathrm{C}$ depleted carbon (Ascough et al. 2005; Philippsen 2013). Different environmental sources of radiocarbon, ${ }^{14} \mathrm{C}$ reservoirs or pools depleted in ${ }^{14} \mathrm{C}$, yield different average ${ }^{12} \mathrm{C} /{ }^{14} \mathrm{C}$ ratios. This being the case, modern samples from these reservoirs can be measured as having apparently old ${ }^{14} \mathrm{C}$ dates. These ${ }^{14} \mathrm{C}$ reservoir effects can alter a sample's apparent age by hundreds or even thousands of years. Stable isotope analysis, used to reconstruct diets, can be 
used to quantify the dietary input from different reservoirs, thereby enabling the estimation of the true age of an individual.

The effect of multiple reservoir effects from different dietary sources on ${ }^{14} \mathrm{C}$ dating has been previously studied by, e.g. Ascough et al. $(2007,2012)$ and Sayle et al. $(2014,2016)$. To address this problem, a series of steps must be taken to accurately date the human remains. Firstly, a multi-isotopic model will be used to help reconstruct the diet of these individuals. Secondly, the presence of any freshwater reservoir effects must be investigated. Thirdly, appropriate $\Delta R$ values will be defined for each individual. Finally, an OxCal model, which considers all available reservoir effects and dietary inputs, will be used to calibrate the ${ }^{14} \mathrm{C}$ dates of these individuals.

Regarding the procurement of these dietary resources, Sámi economies in northern Scandinavia were quite diverse. Sámi cultures have often been subdivided in order to account for these economic differences. The Sea Sámi lived traditionally by combining fishing and small-scale animal husbandry. The term Reindeer Sámi, or Mountain Sámi, describes the nomadic Sámi peoples living as reindeer herders. Forest Sámi traditionally lived by combining fishing in inland rivers and lakes alongside small-scale reindeer-herding (Vorren and Manker 1976:106, 118-119). This investigation into the diets of the Rounala individuals falls into ongoing research and discussion of Sámi subsistence and settlement patterns. A historical map shows that many Forest Sámi settlements were placed close to rivers and lakes (Norstedt and Östlund 2016). This settlement pattern is consistent with ethnographic descriptions of groups with a fish-centered subsistence pattern but perhaps not with a reindeer-centered one (Norstedt and Östlund 2016). It has also been proposed that fish (Norstedt et al. 2014) were more important than has previously been assumed.

\section{MATERIALS}

In total, 19 human skeletal samples from Rounala were anlaysed. Although 23 distinct human individuals were identified during the original excavations, only 21 of the crania were in a condition suitable for recovery. Today only 17 of these 21 crania could be located. A further two human humerus samples from Rounala were sampled for analysis. In addition, 22 faunal samples were analyzed: eight modern fish and 14 reindeer. Three Atlantic salmon were caught from the estuary of Målselva (northern Norway), a 140-km-long river emptying into the Malangen fjord in the Norwegian Sea. Samples of the salmon muscle and bone were taken for stable isotope analysis and ${ }^{14} \mathrm{C}$ dating. Five specimens of freshwater fish were caught from freshwater bodies in northern Sweden; these included four Arctic char and one brown trout. Archaeological and historical samples from 14 reindeer were sampled from a number of sites in northern Sweden (Figure 1). Data from these samples were considered alongside previously published data, including 54 Atlantic cod and 18 Baltic seals, used to infer Baltic fish values.

\section{METHODS}

\section{Human and Reindeer Bone Collagen}

To reconstruct the diet of the humans interred at Rounala, stable isotope analysis was performed on bone collagen extracted from human bones, as well as from faunal bones representing animals that were potentially consumed by the human individuals. Samples of human and reindeer bone powder were obtained using a dentist's drill. Surface layers were discarded to avoid contamination. Bone collagen was subsequently extracted by the method of Brown et al. (1988), a modification of the Longin method (1971). This included an ultrafiltration step to remove the $<30 \mathrm{kDa}$ fraction which potentially contains contaminants of low molecular weight. All sampling and extraction were performed at Stockholm University Archaeological Research Laboratory while subsequent 
EA-IRMS analysis took place at Stockholm University Stable Isotope Laboratory (SIL), Dept. of Geological Sciences, unless otherwise stated. Bone collagen was weighed into tin capsules (ca. $0.5 \mathrm{mg}$ for carbon and nitrogen isotope analysis and ca. 2-5 mg for sulfur isotope analysis) for combustion in a Carlo Erba NC2500 elemental analyzer connected to a continuous flow isotope ratio mass spectrometer - a Finnigan MAT Delta+ for $\delta^{13} \mathrm{C}$ and $\delta^{15} \mathrm{~N}$, and a DeltaV Advantage for $\delta^{34} \mathrm{~S}$ measurements. The precision of the measurements was $\pm 0.15 \%$ or better for both $\delta^{13} \mathrm{C}$ and $\delta^{15} \mathrm{~N}$ ratios, and $\pm 0.2 \%$ or better for $\delta^{34} \mathrm{~S}$ measurements.

\section{Fish Muscle and Bone Collagen}

Arctic char and brown trout bone samples were boiled, after which bone was subsequently mechanically defleshed. Bone collagen was extracted following the same protocol as outlined above with the addition of a lipid removal step after demineralization. A 2:1 dichloromethane: methanol solution was added, after which samples were shaken for two hours, then rinsed with deionized water in excess and subsequently dried in a desiccator overnight.

The bone and flesh of the Atlantic salmon were mechanically separated. Both muscle and bone samples were subject to lipid removal procedures as above. Samples were then placed in a heating block at $70^{\circ} \mathrm{C}$ until dry. Collagen was extracted from these salmon samples using the following method: Bone samples were placed in $8 \mathrm{~mL}$ of $0.6 \mathrm{M} \mathrm{HCl}$ at $4^{\circ} \mathrm{C}$ until demineralized. The samples were rinsed with deionized water and left to gelatinise in $4 \mathrm{~mL}$ of $\mathrm{HCl}(\mathrm{pH} 3)$ in a heating block at $80^{\circ} \mathrm{C}$ until the collagen had fully dissolved (Longin 1971; Richards and Hedges 1999; Colonese et al. 2015). Ultrafilters were rinsed with $0.1 \mathrm{M} \mathrm{NaOH}$ and centrifuged at $850 \mathrm{~g}$ for $8 \mathrm{~min}$ to remove any contaminants. This process was repeated three times with deionized water. The bone samples were centrifuged down to $0.5 \mathrm{~mL}$ and freeze-dried. The lipid-removed muscle samples were freeze-dried and ground down to a powder.

\section{Radiocarbon Dating}

AMS ${ }^{14} \mathrm{C}$ dating was performed on bone collagen from the 19 Rounala human individuals, the modern fish samples, consisting of one Arctic char, one brown trout and three salmon, as well as muscle collagen extracted from the three salmon samples. ${ }^{14} \mathrm{C}$ dating was performed at the AMS facility at the Dept. of Physics and Astronomy at Uppsala University (a few previous dates of human bone had been made at the Radiocarbon Dating Laboratory at Lund University; see Appendix 1).

\section{RESULTS}

All faunal and human samples, except the modern salmon, complied with established collagen quality criteria with regard to yield, carbon and nitrogen concentrations and atomic $\mathrm{C}: \mathrm{N}$ ratio, as well as sulphur concentration, atomic C:S and N:S ratios (DeNiro 1985; Ambrose 1990; Nehlich and Richards 2009) (due to machine failure, one of the fish, REB 1, did not generate any carbon and nitrogen data). Some of the modern salmon samples have C:N ratios slightly out of range and very high sulphur concentrations, the latter affecting the $\mathrm{C}: \mathrm{S}$ and $\mathrm{N}: \mathrm{S}$ ratios. Given that these samples are modern, and that $\mathrm{C}: \mathrm{S}$ and $\mathrm{N}: \mathrm{S}$ ratios are consistent both between muscle and bone collagen from the same individual, and also between individuals, these samples have been included in subsequent analysis.

Stable isotopic results are summarized in Figures 2-3 and Table 4 (detailed data in Appendix 2). The only terrestrial animal in this study, reindeer, display $\delta^{13} \mathrm{C}$ values ranging from $-21.7 \%$ o to $-18.5 \%$ and $\delta^{15} \mathrm{~N}$ values between $2.0 \%$ and $5.9 \%$, consistent with previously analyzed reindeer (Iacumin et al. 2000; Salmi et al. 2015). The $\delta^{34} \mathrm{~S}$ values range from $7.9 \%$ to $12.8 \%$, 


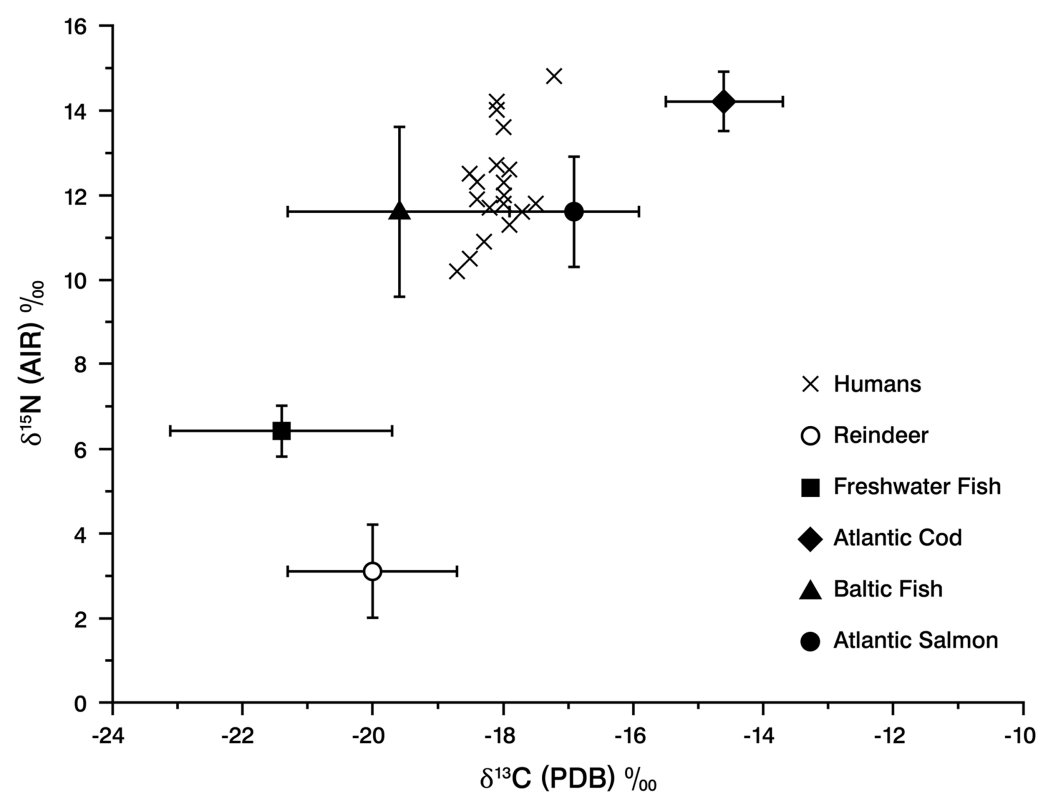

Figure 2 Graph displaying $\delta^{13} \mathrm{C}$ and $\delta^{15} \mathrm{~N}$ values for the Rounala humans and relevant food groups (mean \pm 1 standard deviation). The $\delta^{13} \mathrm{C}$ values for modern samples have been corrected for the Suess effect by $+1.5 \%$. Reindeer $n=14$ (this study), freshwater fish $n=5$ (this study), Baltic fish $n=18$ (Enhus et al. 2011), Atlantic salmon $n=3$ (this study), Atlantic cod $n=51$ (Barrett et al. 2011; Nehlich et al. 2013). See Discussion section for Baltic fish values.

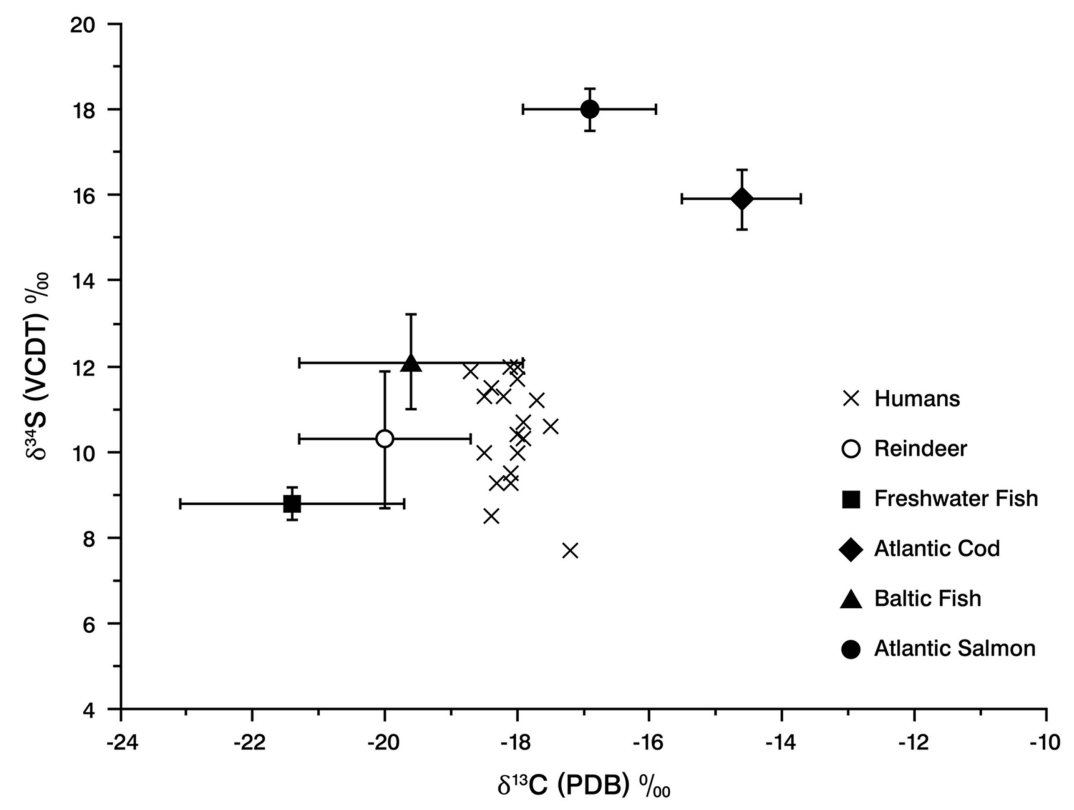

Figure 3 Graph displaying $\delta^{13} \mathrm{C}$ and $\delta^{34} \mathrm{~S}$ values for the Rounala humans and relevant food groups (mean \pm 1 standard deviation). The $\delta^{13} \mathrm{C}$ values for modern samples have been corrected for the Suess effect by $+1.5 \%$. Reindeer $n=14$ (this study), freshwater fish $n=5$ (this study), Baltic fish $n=18$ (Linderholm et al. 2008; Enhus et al. 2011), Atlantic salmon $n=3$ (this study), Atlantic $\operatorname{cod} n=51$ (Barrett et al. 2011; Nehlich et al. 2013). See Discussion section for Baltic fish values. 
reflecting the large geographical area the reindeer derive from. The freshwater fish display $\delta^{13} \mathrm{C}$ values ranging from $-22.6 \%$ to $-19.0 \%$ o, $\delta^{15} \mathrm{~N}$ values between $5.8 \%$ and $7 \%$ and $\delta^{34} \mathrm{~S}$ values range from $8.2 \%$ o to $9.2 \%$. The Atlantic salmon bone samples have $\delta^{13} \mathrm{C}$ values ranging from $-19.5 \%$ to $-17.6 \%$, $\delta^{15} \mathrm{~N}$ values between $10.1 \%$ and $12.4 \%$ and $\delta^{34} \mathrm{~S}$ values between $17.4 \%$ o and $18.3 \%$.

Stable isotope values vary along food chains. Typically, there is a large stepwise trophic shift of between +3 and $5 \%$ in $\delta^{15} \mathrm{~N}$ from prey to consumer (Minagawa and Wada 1984; Bocherens and Drucker 2003). A smaller trophic-level effect of about between +1 and $2 \%$ is observed for $\delta^{13} \mathrm{C}$ values between prey and consumer (DeNiro and Epstein 1978). Trophic level shifts in $\delta^{34} \mathrm{~S}$ values between animals and their diet are $0 \pm 1 \%$ (Barnes and Jennings 2007; Kaufman and Michener 2007).

The isotopic values for the humans range between $-18.5 \%$ and $-17.2 \% \circ\left(\delta^{13} \mathrm{C}\right), 10.2 \%$ and $14.8 \% \circ\left(\delta^{15} \mathrm{~N}\right)$ and $7.7 \% \circ$ and $12 \% \circ\left(\delta^{34} \mathrm{~S}\right)$, showing a wide variation. The $\delta^{13} \mathrm{C}$ and $\delta^{15} \mathrm{~N}$ values are particularly elevated relative to the reindeer, indicating that reindeer did not constitute a major dietary source. Furthermore, the humans have $\delta^{15} \mathrm{~N}$ values similar to the marine fish groups, but considerably lower $\delta^{13} \mathrm{C}$ values, indicating some marine input, but no linear mixing between solely two major food groups. FRUITS (Food Reconstruction Using Isotopic Transferred Signals), a Bayesian computer model for diet reconstruction, will help estimate the contributions of these marine groups (Fernandes et al. 2014).

The results of the ${ }^{14} \mathrm{C}$ dating and stable isotope analysis applied to the human samples are summarized in Table 1. Duplicate ${ }^{14} \mathrm{C}$ measurements were made for humans 6, 10 and 12, due to their larger uncertainties; their ${ }^{14} \mathrm{C}$ ages were calculated using $R \_$Combine in OxCal v.4.3, (Bronk Ramsey 2009; see Appendix 1 for sample details).

Table 1 Stable isotopic ratios and ${ }^{14} \mathrm{C}$ ages of Rounala human samples (see Appendix 1 for details).

\begin{tabular}{llllr}
\hline $\begin{array}{l}\text { Rounala } \\
\text { human }\end{array}$ & $\begin{array}{l}{ }^{14} \mathrm{C} \text { age } \\
(\mathrm{BP})\end{array}$ & $\begin{array}{l}\delta^{13} \mathrm{C} \\
(\%)\end{array}$ & $\begin{array}{l}\delta^{15} \mathrm{~N} \\
(\% o)\end{array}$ & $\begin{array}{r}\delta^{34} \mathrm{~S} \\
(\%)\end{array}$ \\
\hline 1 & $580 \pm 85$ & -17.9 & 11.3 & 10.7 \\
3 & $429 \pm 30$ & -18.5 & 12.5 & 10.0 \\
4 & $414 \pm 30$ & -17.1 & 14.0 & 12.0 \\
5 & $492 \pm 30$ & -18.1 & 12.7 & 9.3 \\
6 & $669 \pm 65$ & -18.4 & 12.3 & 11.5 \\
7 & $371 \pm 31$ & -18.0 & 12.3 & 11.7 \\
8 & $527 \pm 30$ & -18.4 & 11.9 & 8.5 \\
9 & $460 \pm 30$ & -18.0 & 13.6 & 10.4 \\
10 & $472 \pm 28$ & -17.9 & 12.6 & 10.3 \\
11 & $451 \pm 30$ & -17.5 & 11.8 & 10.6 \\
12 & $513 \pm 29$ & -17.7 & 11.6 & 11.2 \\
13 & $513 \pm 30$ & -18.0 & 12.0 & 10.0 \\
14 & $407 \pm 30$ & -18.5 & 10.5 & 11.3 \\
16 & $270 \pm 30$ & -18.7 & 11.7 & 11.9 \\
18 & $337 \pm 30$ & -18.2 & 14.2 & 9.5 \\
20 & $552 \pm 30$ & -18.1 & 11.8 & 12.0 \\
21 & $287 \pm 30$ & -18.0 & 14.8 & 7.7 \\
L17a & $457 \pm 32$ & -17.2 & 10.9 & 9.3 \\
L17b & $550 \pm 32$ & -18.3 & &
\end{tabular}


Table 2 Stable isotope ratios and calibrated ${ }^{14} \mathrm{C}$ ages for the fish samples.

\begin{tabular}{llllllll}
\hline Sample & Tissue & $\begin{array}{l}{ }^{14} \mathrm{C} \text { age } \\
\text { pMC }\end{array}$ & Cal AD (68.2\%) & Cal AD (95.4\%) & $\begin{array}{l}\delta^{13} \mathrm{C} \\
(\%)\end{array}$ & $\begin{array}{l}\delta^{15} \mathrm{~N} \\
(\%)\end{array}$ & $\begin{array}{l}\delta^{34} \mathrm{~S} \\
(\%)\end{array}$ \\
\hline Salmon 1 & Collagen & $104.8 \pm 0.3$ & $2007.94-2009.50$ & $1956.54-2009.53$ & -18.2 & 12.4 & 18.3 \\
Salmon 2 & Collagen & $105.4 \pm 0.3$ & $2007.02-2009.52$ & $1956.63-2009.53$ & -17.6 & 12.3 & 17.4 \\
Salmon 3 & Collagen & $104.2 \pm 0.3$ & $1956.54-2009.49$ & $1956.28-2009.53$ & -19.5 & 10.1 & 18.2 \\
Salmon 1 & Muscle & $105.2 \pm 0.3$ & $2007.43-2009.52$ & $1956.61-2009.53$ & -19.9 & 13.7 & 18.4 \\
Salmon 2 & Muscle & $105.5 \pm 0.3$ & $2006.99-2009.52$ & $1956.65-2009.53$ & -19.8 & 13.7 & 18.4 \\
Salmon 3 & Muscle & $104.7 \pm 0.3$ & $2007.94-2009.50$ & $1956.53-2009.53$ & -20.6 & 11.4 & 16.7 \\
Arctic char & Collagen & $104.8 \pm 0.5$ & $1956.70-2009.52$ & $1956.53-2009.52$ & -24.1 & 5.8 & 9.2 \\
Brown trout & Collagen & $105.0 \pm 0.5$ & $2007.39-2009.52$ & $1956.55-2009.52$ & -23.1 & 7.0 & 9.2 \\
\hline
\end{tabular}

Table 2 displays stable isotopic and calibrated ${ }^{14} \mathrm{C}$ data for the fish sampled, demonstrating that all ${ }^{14} \mathrm{C}$ dates are consistent with modern samples - both the freshwater species and the Atlantic salmon. Calibrated dates were calculated from ${ }^{14} \mathrm{C}$ pMC values using the ${ }^{14} \mathrm{CALIBomb}$ software (Reimer and Reimer 2004). At $95.4 \%$ probability, the collagen samples are clearly modern.

Salmon are a migratory fish species, spending some time in marine systems and traveling upriver to spawn. The amount of time these salmon had spent in the river was not known. Due to the difference in turnover rates between bone and muscle tissue, the effect of migration on the ${ }^{14} \mathrm{C}$ values of these fish could be investigated. There was, however, no reservoir effect noticed in any of the tissues. This was surprising considering the potential migration of these species into marine waters, where there is a known reservoir effect. There appears to be some difference in terms of the $\delta^{34} \mathrm{~S}$ values between salmon tissues, which could be explained by differing turnover rates. Salmon muscle $\delta^{13} \mathrm{C}$ values were depleted relative to bone collagen whereas $\delta^{15} \mathrm{~N}$ muscle values were enriched. $\delta^{34} \mathrm{~S}$ values were more variable between tissues. Arctic char and brown trout are landlocked freshwater species in this area, and treated as their own group in the FRUITS modeling. The salmon samples also form their own group.

\section{DISCUSSION}

\section{Defining Marine $\Delta \mathrm{R}$ Values}

$\Delta \mathrm{R}$ values for both the North Norwegian Sea and the Bothnian Sea were calculated. $\Delta \mathrm{R}$ values represent regional offsets from the global average surface water marine reservoir effect, the $\Delta \mathrm{R}$ of this average being $\Delta \mathrm{R}=0$ (Russell et al. 2011). Table 3 presents the marine samples used to calculate the $\Delta \mathrm{R}$ values for the North Norwegian Sea and the Bothnian Sea. Note the low $\Delta \mathrm{R}$ value that is calculated for the Bothnian Sea, which is due to the number of freshwater rivers emptying into the north of the Baltic Sea. In fact, the $\Delta \mathrm{R}$ value for the northernmost part of the Baltic, the Gulf of Bothnia, is likely to be even lower, considering the correlation between salinity and reservoir age (Lougheed et al. 2013), but there is currently no data available on this.

\section{Dietary Modeling}

To investigate the diet of the Rounala individuals, FRUITS 3.0 modeling software (Fernandes et al. 2014) was employed. This required the isotopic characterization of various food groups which were likely to have contributed to the diet of the Rounala individuals. From historical sources, it is known that fish were an important dietary input, also for the people in Rounala (Nickul 1977:3, 10, 15, 32; Ruong 1982:22-26; Fjellström 1985:22-44; Korpijaakko-Labba 1994:81-86, 91-93; Bergman and Ramqvist 2017). In northern Scandinavia there are many 
Table 3 Summary of marine samples and $\Delta \mathrm{R}$ values for the Bothnian Sea and North Norwegian Sea. Weighted mean $\Delta \mathrm{R}$ values and uncertainties calculated using the Calib Marine Reservoir Correction tool.

\begin{tabular}{|c|c|c|c|c|c|c|}
\hline Source & Species & $\begin{array}{l}\text { Collection } \\
\text { year }\end{array}$ & Coordinates & ${ }^{14} \mathrm{C}$ age $\mathrm{BP}$ & $\Delta \mathrm{R}$ & Publication \\
\hline \multirow[t]{3}{*}{ Bothnian Sea } & $\begin{array}{c}\text { Macoma } \\
\text { balthica }\end{array}$ & 1934 & $63^{\circ} 25^{\prime} \mathrm{N}, 20^{\circ} 47^{\prime} \mathrm{E}$ & $265 \pm 50$ & $-192 \pm 55$ & $\begin{array}{l}\text { Lougheed et al. } \\
2013\end{array}$ \\
\hline & $\begin{array}{r}\text { Macoma } \\
\text { balthica }\end{array}$ & 1934 & $63^{\circ} 04^{\prime} \mathrm{N}, 20^{\circ} 50^{\prime} \mathrm{E}$ & $275 \pm 45$ & $-187 \pm 51$ & $\begin{array}{l}\text { Lougheed et al. } \\
2013\end{array}$ \\
\hline & & & & $\begin{array}{l}\text { Weighted } \\
\text { mean } \Delta \mathrm{R}\end{array}$ & $-189 \pm 4$ & \\
\hline \multirow[t]{5}{*}{$\begin{array}{l}\text { North } \\
\text { Norwegian Sea }\end{array}$} & $\begin{array}{l}\text { Balaenoptera } \\
\text { borealis }\end{array}$ & 1894 & $70^{\circ} 38^{\prime} \mathrm{N}, 22^{\circ} 00^{\prime} \mathrm{E}$ & $479 \pm 20$ & $-3 \pm 20$ & $\begin{array}{l}\text { Mangerud et al. } \\
2006\end{array}$ \\
\hline & $\begin{array}{l}\text { Balaenoptera } \\
\text { borealis }\end{array}$ & 1879 & $70^{\circ} 38^{\prime} \mathrm{N}, 22^{\circ} 00^{\prime} \mathrm{E}$ & $527 \pm 50$ & $51 \pm 50$ & $\begin{array}{l}\text { Mangerud et al. } \\
2006\end{array}$ \\
\hline & Mytilus edulis & 1922 & $70^{\circ} 16^{\prime} \mathrm{N}, 23^{\circ} 24^{\prime} \mathrm{E}$ & $546 \pm 57$ & $96 \pm 57$ & Mangerud 1972 \\
\hline & $\begin{array}{l}\text { Chlamys } \\
\text { islandica }\end{array}$ & 1857 & $69^{\circ} 39^{\prime} \mathrm{N}, 18^{\circ} 18^{\prime} \mathrm{E}$ & $548 \pm 37$ & $65 \pm 37$ & $\begin{array}{l}\text { Mangerud and } \\
\text { Gulliksen } \\
1975\end{array}$ \\
\hline & & & & $\begin{array}{l}\text { Weighted } \\
\text { mean } \Delta \mathrm{R}\end{array}$ & $17 \pm 36$ & \\
\hline
\end{tabular}

Table 4 Summary of average $\delta^{13} \mathrm{C}, \delta^{15} \mathrm{~N}$, and $\delta^{34} \mathrm{~S}$ values with standard deviations of faunal groups, see Appendix 3 for individual samples (Barrett et al. 2011; Nehlich et al. 2013). Baltic fish values calculated from Enhus et al. (2011) and Linderholm et al. (2008), see main text.

\begin{tabular}{lrlrr}
\hline Faunal group & Number of samples & \multicolumn{1}{l}{$\begin{array}{l}\delta^{13} \mathrm{C} \\
(\%)\end{array}$} & \multicolumn{1}{c}{$\begin{array}{l}\delta^{15} \mathrm{~N} \\
(\%)\end{array}$} & \multicolumn{1}{c}{$\begin{array}{l}\delta^{34} \mathrm{~S} \\
(\%)\end{array}$} \\
\hline Reindeer & 14 & $-20.0 \pm 1.3$ & $3.1 \pm 1.1$ & $10.3 \pm 1.6$ \\
Freshwater fish & 5 & $-21.4 \pm 1.7$ & $6.4 \pm 0.6$ & $8.8 \pm 0.4$ \\
Baltic fish & 18 & $-19.6 \pm 1.7$ & $11.6 \pm 2.0$ & $12.1 \pm 1.1$ \\
Atlantic salmon & 3 & $-16.9 \pm 1.0$ & $11.6 \pm 1.3$ & $18.0 \pm 0.5$ \\
Atlantic cod & 51 & $-14.6 \pm 0.9$ & $14.2 \pm 0.7$ & $15.9 \pm 0.7$ \\
\hline
\end{tabular}

lakes and large rivers from which freshwater fish would have been caught. Because Rounala is positioned between the North Norwegian Sea $(100 \mathrm{~km})$ and the north Baltic Sea $(330 \mathrm{~km})$, fish from both marine water bodies also need to be considered as a food source. Reindeer too were considered as a potentially important dietary resource. Each dietary group was defined by their $\delta^{13} \mathrm{C}, \delta^{15} \mathrm{~N}$, and $\delta^{34} \mathrm{~S}$ values, respectively, and the proportions of three different aquatic resources were calculated by this model (Table 4, Appendix 3). The $\delta^{13} \mathrm{C}$ measurements for modern collagen samples were adjusted for the Suess effect by adding 1.5\%o (Keeling 1979). FRUITS models were both non-routed and concentration independent.

Few studies using stable isotope data from the North Baltic are published. In order to isotopically define the Baltic fish food group, published seal data was considered. Enhus et al. (2011) measured the $\delta^{13} \mathrm{C}$ and $\delta^{15} \mathrm{~N}$ values of bone collagen from one harbour seal, eight grey seal and eight ringed seal. In total, these 17 individual seals from the North Baltic yielded $\delta^{13} \mathrm{C}$ and $\delta^{15} \mathrm{~N}$ values of 
$-18.1 \pm 1.6$ and $15.6 \pm 1.7$ respectively. These values were adjusted to represent the Baltic fish consumed by the seals, by subtracting $1.5 \%$ from the $\delta^{13} \mathrm{C}$ value and $4 \%$ from the $\delta^{15} \mathrm{~N}$ value to correct for the trophic-level shift (the application of different fractionation offsets between $3 \%$ and $6 \%$ for $\delta^{15} \mathrm{~N}$ made no substantial difference). For each Baltic fish isotopic value, the root sum squared of the associated fractionation offsets and the standard deviation of each isotopic value was taken to be the uncertainty. A $\delta^{34} \mathrm{~S}$ value of $12.6 \%$ was measured from a seal sample that was recovered from Björned, Torsåker parish, Ångermanland (Linderholm et al. 2008), from which we subtracted $0.5 \%$, and assumed a standard deviation to equal $1 \%$. These uncertainties can be seen in Table 4.

Isotopic values for relevant dietary groups (Table 4) were placed into FRUITS models (Fernandes et al. 2014). The models assumed fractionation offsets of $+1.5 \pm 0.5 \%$ o for $\delta^{13} \mathrm{C}$ values, $+4 \pm 1 \%$ o for $\delta^{15} \mathrm{~N}$ values and $+0.5 \pm 0.5 \%$ o for $\delta^{34} \mathrm{~S}$ values between the collagen of the food source and consumer. For each human sample, uncertainties of $0.15 \%$ were applied to carbon and nitrogen measurements and $0.2 \%$ o for sulfur measurements, in line with instrumentation error. No dietary priors were applied to the models. The purpose of these models were to estimate the dietary input of aquatic sources which carry with them a ${ }^{14} \mathrm{C}$ reservoir effect.

\section{OxCal Modeling}

Two OxCal 4.3 models (Bronk Ramsey 2009) were prepared as part of the recalibration of the Rounala individuals, one "mixed marine-reservoirs" model and one "Baltic reservoir" model. Based on the ${ }^{14} \mathrm{C}$ dates of modern freshwater fish and salmon, no reservoir effect from freshwater fish or from Atlantic salmon (or from reindeer) is considered. Both OxCal models required separate dietary analysis to assess marine protein contributions.

The first OxCal model, "mixed marine-reservoirs," assumed dietary inputs from reindeer, freshwater, Atlantic cod and Baltic fish food groups. Because each human was found to consume different amounts of Baltic and Atlantic resources, respectively, and because samples from these two environments carry different $\Delta \mathrm{R}$ values, each human sample was assigned a unique $\Delta R$ value. These unique $\Delta R$ values were averages of the Baltic and Atlantic $\Delta R$ values, weighted according to the mean Atlantic and Baltic dietary inputs of each individual, as calculated by the FRUITS model. The errors associated with the Baltic and Atlantic $\Delta \mathrm{R}$ values were propagated to 36.2 , and this value was set as the uncertainty for each consumer's unique $\Delta \mathrm{R}$ values. The data was calibrated against the IntCal13 and Marine13 curves (Reimer et al. 2013). The total marine dietary input for each individual was calculated by combining their Baltic and Atlantic mean marine input estimates. The total marine dietary input uncertainty was taken to be the root sum squared of the Baltic and Atlantic mean estimates. The data used to construct this model have been summarized in Table 5 .

The second OxCal model, "Baltic reservoir," considered some historical information concerning the dietary practices of these individuals. On historical grounds, it is known that salmon were particularly important to the Sámi living in the north of Scandinavia; salmon fishing was practiced widely along several rivers (Kent 2014:240-246). For the people in Rounala, the river of Storfjordselva, characterized as a good salmon carrying river, was particularly important (Korpijaakko-Labba 1994:91f; Guttormsen 2005:431, 417). As such, reindeer, freshwater fish, Baltic fish, and Atlantic salmon were considered as part of a FRUITS model, whereas Atlantic cod was excluded. Because no reservoir effect could be measured in the salmon sampled in this study, this OxCal model considered only Baltic $\Delta \mathrm{R}$ values and Baltic marine dietary estimates 
Table 5 Summary for information entered into the "mixed marine-reservoirs" OxCal model.

\begin{tabular}{|c|c|c|c|c|c|c|c|c|}
\hline \multirow[b]{2}{*}{$\begin{array}{l}\text { Rounala } \\
\text { consumer }\end{array}$} & \multirow[b]{2}{*}{$\begin{array}{l}{ }^{14} \mathrm{C} \text { age } \\
(\mathrm{BP})\end{array}$} & \multicolumn{6}{|c|}{ Marine dietary inputs (\%) } & \multirow[b]{2}{*}{$\begin{array}{l}\text { Weighted } \\
\Delta \mathrm{R}\end{array}$} \\
\hline & & $\begin{array}{l}\text { Baltic } \\
\text { fish }\end{array}$ & \pm & $\begin{array}{l}\text { Atlantic } \\
\text { cod }\end{array}$ & \pm & $\begin{array}{l}\text { Total } \\
\text { marine }\end{array}$ & \pm & \\
\hline$\overline{1}$ & $580 \pm 85$ & 19.8 & 13.0 & 12.9 & 7.7 & 32.7 & 15.1 & -107.8 \\
\hline 3 & $429 \pm 30$ & 23.4 & 15.7 & 9.1 & 6.5 & 32.5 & 17.0 & -131.2 \\
\hline 4 & $414 \pm 30$ & 31.4 & 19.6 & 25.1 & 11.7 & 56.5 & 22.8 & -97.5 \\
\hline 5 & $492 \pm 30$ & 22.3 & 14.2 & 7.3 & 5.5 & 29.5 & 15.2 & -138.2 \\
\hline 6 & $670 \pm 65$ & 26.9 & 17.2 & 14.9 & 9.2 & 41.8 & 19.5 & -115.5 \\
\hline 7 & $371 \pm 31$ & 26.2 & 17.2 & 16.3 & 8.9 & 42.6 & 19.3 & -109.9 \\
\hline 8 & $527 \pm 30$ & 14.5 & 11.7 & 4.9 & 4.5 & 19.4 & 12.6 & -136.8 \\
\hline 9 & $460 \pm 30$ & 31.0 & 18.4 & 11.8 & 7.9 & 42.8 & 20.0 & -132.2 \\
\hline 10 & $515 \pm 85$ & 26.1 & 17.9 & 12.0 & 8.1 & 38.1 & 19.7 & -124.3 \\
\hline 11 & $451 \pm 30$ & 23.0 & 16.2 & 13.6 & 8.3 & 36.5 & 18.2 & -112.5 \\
\hline 12 & $395 \pm 100$ & 22.7 & 16.7 & 15.6 & 8.6 & 38.4 & 18.8 & -105.1 \\
\hline 13 & $513 \pm 30$ & 19.7 & 14.3 & 10.3 & 6.9 & 30.0 & 15.8 & -118.4 \\
\hline 14 & $407 \pm 30$ & 19.8 & 14.9 & 11.6 & 7.1 & 31.4 & 16.5 & -112.9 \\
\hline 16 & $270 \pm 30$ & 20.9 & 14.2 & 11.6 & 7.3 & 32.5 & 16.0 & -115.7 \\
\hline 18 & $337 \pm 30$ & 20.3 & 14.1 & 15.2 & 7.9 & 35.4 & 16.1 & -100.8 \\
\hline 20 & $552 \pm 30$ & 33.9 & 18.5 & 7.8 & 6.1 & 41.7 & 19.5 & -150.4 \\
\hline 21 & $287 \pm 30$ & 23.1 & 15.8 & 18.2 & 9.3 & 41.3 & 18.4 & -98.1 \\
\hline L17a & $457 \pm 32$ & 48.3 & 21.2 & 4.8 & 5.2 & 53.1 & 21.8 & -170.2 \\
\hline $\mathrm{L} 17 \mathrm{~b}$ & $550 \pm 32$ & 15.2 & 12.9 & 6.7 & 5.4 & 22.0 & 14.0 & -126.0 \\
\hline
\end{tabular}

and calibrated samples against IntCal13 and Marine13 curves (Reimer et al. 2013) (Table 6). This assumes that the only reservoir effect acting on the Rounala consumers would come from the Baltic.

Some prior information concerning the church and the graveyard's use was included in both OxCal models. It is known on historical grounds that the church was used less frequently by 1643 (Lidén et al. in press). The church building itself was sold in 1796 and dismantled (Wiklund 1916:12). Based on this, a maximum calendar date for the buried individuals of 1800 AD was used, which gives some room for error. The model would not accept age estimates for samples which fell after this date. No earliest date was set.

The probability distributions of the Rounala consumers as calculated by both OxCal models are displayed in Figure 4. The distribution plots represent a range of possible ages. The range takes into account any uncertainties included in the OxCal model. Here, uncertainties associated with $\Delta \mathrm{R}$ values, marine dietary contribution and calibration curves have led to some broad probability distributions, even at $68.2 \%$ probability. The differences between the two OxCal models are minor. In general, the model which assumed only salmon constituted the Atlantic dietary contribution (the "Baltic reservoir" model), yielded slightly older mean estimates. The two models, however, share a similar pattern. The amount of Atlantic salmon consumed by the Rounala individuals, relative to Atlantic cod consumed, cannot be estimated with any reasonable certainty. Given the overlap of the two calibration models, this should not affect the calibration of their ${ }^{14} \mathrm{C}$ dates. Dashed lines at $1559 \mathrm{AD}$ and $1800 \mathrm{AD}$ represent the earliest possible founding of the church and the latest possible abandonment of the church, respectively, based on historical records. The distribution plots, relative to the estimates of the 
Table 6 Summary for information entered into the "Baltic reservoir" OxCal model, assuming a $\Delta \mathrm{R}$ value of $-189 \pm 4$.

\begin{tabular}{llll}
\hline & & \multicolumn{2}{c}{ Dietary contribution $(\%)$} \\
\cline { 3 - 4 } Consumer & ${ }^{14}$ C age $(\mathrm{BP})$ & Baltic & \pm \\
\hline 1 & $580 \pm 85$ & 22.2 & 14.3 \\
3 & $429 \pm 30$ & 26.6 & 15.4 \\
4 & $414 \pm 30$ & 45.1 & 19.4 \\
5 & $492 \pm 30$ & 27.2 & 16.9 \\
6 & $670 \pm 65$ & 28.7 & 16.1 \\
7 & $371 \pm 31$ & 27.0 & 16.5 \\
8 & $527 \pm 30$ & 16.1 & 14.7 \\
9 & $460 \pm 30$ & 43.3 & 17.1 \\
10 & $515 \pm 85$ & 26.8 & 14.2 \\
11 & $451 \pm 30$ & 20.3 & 12.9 \\
12 & $395 \pm 100$ & 24.5 & 15.0 \\
13 & $513 \pm 30$ & 25.1 & 13.4 \\
14 & $407 \pm 30$ & 18.7 & 13.6 \\
16 & $270 \pm 30$ & 17.9 & 17.7 \\
18 & $337 \pm 30$ & 29.7 & 17.8 \\
20 & $552 \pm 30$ & 41.4 & 19.5 \\
21 & $287 \pm 30$ & 28.0 & 11.3 \\
L17a & $457 \pm 32$ & 57.5 & \\
L17b & $550 \pm 32$ & 14.5 & \\
\hline
\end{tabular}

church's founding, indicate that it is likely that many individuals (to varying degrees of certainty) were interred in the cemetery before 1559 AD. It must be noted, however, that the events being dated are the formations of the bone tissues sampled rather than the date of death. In some individuals, part of the tissue may have formed up to 20 years prior to their burial, depending on their age at death. Given this, the date of some of the individual's burial events may have been slightly overestimated (their true burial dates being more recent than estimated). This is likely to be the case for all adult individuals (excluding the subadult individuals 16, 18, 20, and 21). From the available evidence presented here and considering all uncertainties, however, the site of the cemetery was most likely in use for a time prior to the church's founding, as well as after its alleged abandonment. Calibrated without prior date constraints, samples 16 and 21 yield later dates, closer to present, especially for the mixed marine model. Knowing their archaeological contexts, this demonstrates the importance of the inclusion of the date constraint.

\section{CONCLUSION}

Despite historical records on the building and abandonment of the church at Rounala, the relationship between the cemetery and the church had yet to be investigated fully. The timing of the burial of these individuals is important for wider discussions concerning the religious practices of these individuals as well as the Christianization of the Sámi in this region. It was demonstrated, by measuring the ${ }^{14} \mathrm{C}$ values of modern freshwater fish from the region, that there does not appear to be a freshwater reservoir effect in the bodies of water investigated; this was an important point to illustrate. From the available evidence presented here and considering all uncertainties, the site of the cemetery was most likely in use for a time prior to the church's earliest possible founding, possibly as early as the 14th century, but also after its 


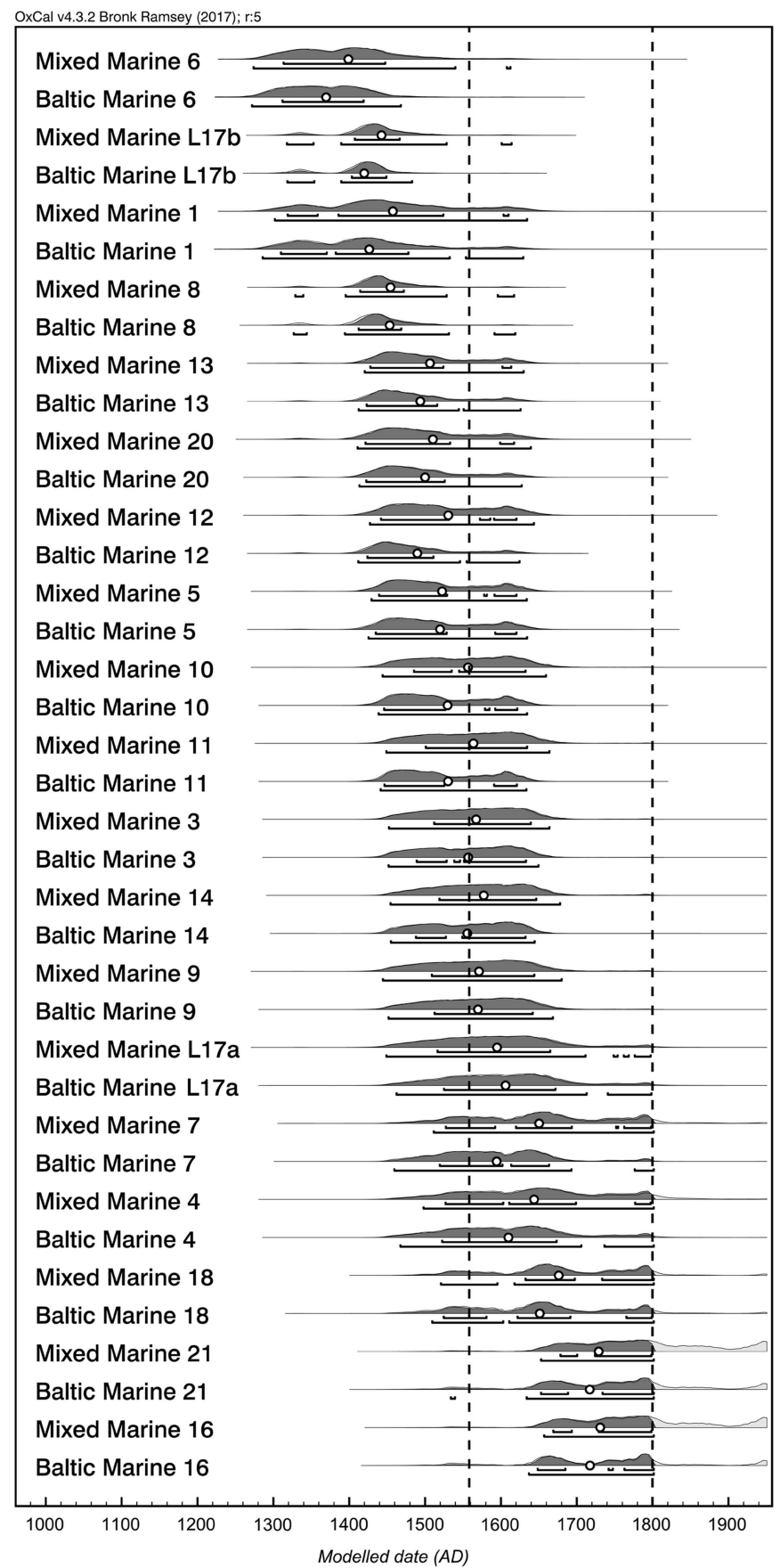

Figure 4 OxCal plot displaying the $68.2 \%$ and $95.4 \%$ probability distributions and mean age estimates (marked with a circle) of both models for Rounala samples. Dashed lines at 1559 AD and 1800 AD represent the earliest possible founding and the latest possible abandonment of the church, respectively, based on historical records. The model would not accept age estimates for samples which fell after 1800 (see main text). 
alleged abandonment. The majority of the sampled individuals, however, appear to have been buried throughout the graveyard's use as a church site.

\section{ACKNOWLEDGMENTS}

This project has received funding from the European Union's EU Framework Programme for Research and Innovation Horizon 2020 under Marie Curie Actions Grant Agreement No. 676154. This research has benefited from several useful discussions with Prof. Peter Jordan (The Arctic Centre, University of Groningen). Thanks go to Geoffrey Metz at the Museum Gustavianum in Uppsala, Leena Drenzel at the Swedish History Museum in Stockholm, Kjell-Åke Aronsson at Ájtte - the Swedish Mountain and Sami Museum in Jokkmokk, to the Nordic Museum in Stockholm, for access to the skeletal material, Anna Kjellström for making the osteological analysis of the human material, to Charlotte Damm for the Atlantic salmon, and to Heike Siegmund at SIL for running the EA-IRMS. Some of the stable isotope data formed part of MF's master's thesis (Fjellström 2011).

\section{SUPPLEMENTARY MATERIAL}

To view supplementary material for this article, please visit https://doi.org/10.1017/ RDC.2018.78

\section{REFERENCES}

Ambrose SH. 1990. Preparation and characterization of bone and tooth collagen for isotopic analysis. Journal of Archaeological Science 17(4):431-51.

Aronsson K-A. 2013. Research on human remains from indigenous people: reflections from an archaeological perspective (with an example from Rounala). In: Fossheim H, editor. More Than Just Bones: Ethics and Research on Human Remains. Oslo: The Norwegian National Research Ethics Committees. p 65-79.

Ascough PL, Church MJ, Cook GT, Dunbar E, Gestsdóttir H, McGovern TH, Dugmore AJ, Friðriksson A, Edwards KJ. 2012. Radiocarbon reservoir effects in human bone collagen from northern Iceland. Journal of Archaeological Science 39(7):2261-71.

Ascough PL, Cook GT, Church MJ, Dugmore AJ, McGovern TH, Dunbar E, Einarsson E, Friðriksson A, Gestsdottir H. 2007. Reservoirs and radiocarbon: ${ }^{14} \mathrm{C}$ dating problems in Myvatnssveit, northern Iceland. Radiocarbon 49(2):947-61.

Ascough PL, Cook GT, Dugmore AJ. 2005. Methodological approaches to determining the marine radiocarbon reservoir effect. Progress in Physical Geography 29(4):532-47.

Barnes C, Jennings S. 2007. Effect of temperature, ration, body size and age on sulphur isotope fractionation in fish. Rapid Communications in Mass Spectrometry 21(8):1461-7.

Barrett JH, Orton D, Johnstone C, Harland J, Van Neer W, Ervynck A, Roberts C, Locker A, Amundsen C, Enghoff IB, Hamilton-Dyer S, Heinrich D, Hufthammer AK, Jones AKG, Jonsson L, Makowiecki D, Pope P, O’Connell
TC, de Roo T, Richards M. 2011. Interpreting the expansion of sea fishing in medieval Europe using stable isotope analysis of archaeological cod bones. Journal of Archaeological Science 38 (7):1516-24.

Bergman I, Ramqvist P. 2017. Farmer-fishermen: Interior lake fishing and inter-cultural and intracultural relations among coastal and interior Sámi communities in northern Sweden AD 1200-1600. Acta Borealia 34(2):134-58.

Bocherens H, Drucker D. 2003. Trophic level isotopic enrichment of carbon and nitrogen in bone collagen: case studies from recent and ancient terrestrial ecosystems. International Journal of Osteoarchaeology 13(1-2):46-53.

Bronk Ramsey C. 2009. Bayesian analysis of radiocarbon dates. Radiocarbon 51(1):337-60.

Brown TA, Nelson DE, Vogel JS, Southon JR. 1988. Improved collagen extraction by modified Longin method. Radiocarbon 30(2):171-7.

Colonese AC, Thomas F, Lucquin A, Firth D, Charlton S, Robson HK, Alexander M, Craig OE. 2015. Archaeological bone lipids as palaeodietary markers. Rapid Communications in Mass Spectrometry 29:611-8

DeNiro MJ. 1985. Postmortem preservation and alteration of in vivo bone collagen isotope ratios in relation to palaeodietary reconstruction. Nature 317(6040):806.

DeNiro MJ, Epstein S. 1978. Influence of diet on the distribution of carbon isotopes in animals. Geochimica et Cosmochimica Acta 42(5):495506.

Enhus C, Boalt E, Bignert A. 2011. A retrospective study of metals and stable isotopes in seals from 
Swedish waters. Swedish Museum of Natural History Report 5:2011. Stockholm.

Fernandes R, Millard AR, Brabec M, Nadeau M-J, Grootes P. 2014. Food reconstruction using isotopic transferred signals (FRUITS): a Bayesian model for diet reconstruction. PLoS One 9(2):e87436.

Fjellström M. 2011. Stable Isotope Analysis and Ethical Issues Surrounding a Human Skeleton Material from Rounala in Karesuando Parish [master's thesis]. Stockholm University: Archaeological Research Laboratory.

Fjellström P. 1985. Samernas samhälle i tradition och nutid. Stockholm: Norstedt.

Guttormsen H. 2005. Lyngen regionhistorie. Bind 1. Lyngen: Lyngen bygdebok.

Hoppe G. 1945. Vägarna inom Norrbottens län: Studier över den trafikgeografiska utvecklingen från 1500 - talet till våra dagar. Uppsala.

Iacumin P, Nikolaev V, Ramigni M. 2000. C and N stable isotope measurements on Eurasian fossil mammals, 40000 to 10000 years BP: Herbivore physiologies and palaeoenvironmental reconstruction. Palaeogeography, Palaeoclimatology, Palaeoecology 163:33-47.

Kaufman L, Michener RH. 2007. Stable isotope ratios as tracers in marine food webs: An update. In: Michener R, Lajtha K, editors. Stable Isotopes in Ecology and Environmental Science. Oxford: Blackwell Scientific Publications.

Keeling CD. 1979. The Suess effect: ${ }^{13}$ Carbon${ }^{14}$ Carbon interrelations. Environment International 2(4-6):229-300.

Kent N. 2014. The Sámi Peoples of the North: A Social and Cultural History. London.

Korpijaakko-Labba K. 1994. Om samernas rättsliga ställning $i$ Sverige-Finland. En rättshistorisk utredning av markanvändningsförhållanden och -rättigheter $i$ Västerbottens lappmark före mitten av 1700talet. Helsingfors: Juristförbundets förlag.

Lidén K, Fjellström M, Wallerström T, in press. Nya resultat från Eskil Olssons Rounala-utgrävning 1915. In: T Wallerström Kunglig makt och samiska bosättningsmönster: Studier kring Väinö Tanners vinterbyteori. Instituttet for sammenlignende kulturforskning. Serie B. Skrifter CLXV. Oslo: Novus forlag.

Linderholm A, Andersson K, Mörth C-M, Grundberg L, Hårding B, Lidén K. 2008. An early Christian cemetery at Björned in northern Sweden. Fornvännen 103(3):176-89.

Longin R. 1971. New method of collagen extraction for radiocarbon dating. Nature 230: 241-2

Lougheed BC, Filipsson HL, Snowball I. 2013. Large spatial variations in coastal ${ }^{14} \mathrm{C}$ reservoir age - a case study from the Baltic Sea. Climate of the Past 9(3):1015-28.

Mangerud J. 1972. Radiocarbon dating of marine shells, including a discussion of apparent age of recent shells from Norway. Boreas 1(2):143-72.

Mangerud J, Bondevik S, Gulliksen S, Hufthammer AK, Høisæter T. 2006. Marine ${ }^{14} \mathrm{C}$ reservoir ages for 19th century whales and molluscs from the North Atlantic. Quaternary Science Review 25 (23):3228-45.

Mangerud J, Gulliksen S. 1975. Apparent radiocarbon ages of recent marine shells from Norway, Spitsbergen, and Arctic Canada. Quaternary Research 5(2):263-73.

Manker E. 1961. Lappmarksgravar: Dödsföreställningar och gravskick $i$ lappmarkerna. Anteckningar. Stockholm.

Minagawa M, Wada E. 1984. Stepwise enrichment of ${ }^{15} \mathrm{~N}$ along food chains: Further evidence and the relation between $\delta^{15} \mathrm{~N}$ and animal age. Geochimica et Cosmochimica Acta 48(5): 1135-40.

Nehlich O, Barrett JH, Richards MP. 2013. Spatial variability in sulphur isotope values of archaeological and modern cod (Gadus morhua). Rapid Communications in Mass Spectrometry 27 (20):2255-62.

Nehlich O, Richards M. 2009. Establishing collagen quality criteria for sulphur isotope analysis of archaeological bone collagen. Archaeological and Anthropological Sciences 1(1):59-75.

Nickul K. 1977. The Lappish Nation: Citizens of Four Countries. Uralic and Altaic Series, Vol. 122. Bloomington.

Norstedt G, Axelsson A-L, Östlund L. 2014. Exploring Pre-Colonial resource control of individual Sami households. Arctic 67(2):223-37.

Norstedt G, Östlund L. 2016. Fish or reindeer? The relation between subsistence patterns and settlement patterns among the forest Sami. Arctic Anthropology 53(1):22-36.

Philippsen B. 2013. The freshwater reservoir effect in radiocarbon dating. Heritage Science 1(1):24

Rasmussen S. 2016. Samisk integrering $i$ norsk og svensk kirke i tidlig nytid: En komparasjon mellom Finnmark og Torne lappmark. The Arctic University of Norway, Tromsø.

Reimer PJ, Bard E, Bayliss A, Warren Beck J, Blackwell PG, Bronk Ramsey C, Buck CE, Cheng H, Lawrence Edwards R, Friedrich M, Grootes PM, Guilderson TP, Haflidason H, Hajdas I, Hatté C, Heaton TJ, Hoffmann DL, Hogg AG, Hughen KA, Felix Kaiser K, Kromer B, Manning SW, Niu M, Reimer RW, Richards DA, Marian Scott E, Southon JR, Staff RA, Turney CSM, van der Plicht J. 2013. IntCal13 and Marine13 Radiocarbon age calibration curves $0-50,000$ years cal BP. Radiocarbon 55(4):1869-87.

Reimer R, Reimer P. 2004. CALIBomb - calibration of post-bomb C-14 data. Online software: http:// calib.org/CALIBomb/

Richards MP, Hedges REM. 1999. Stable Isotope Evidence for Similarities in the Types of Marine Foods Used by Late Mesolithic Humans at Sites Along the Atlantic Coast of Europe. Journal of Archaeological Science 26:717-22.

Ruong I. 1982. Samerna i historien och nutiden. Aldus akademi, 4th edition. Stockholm. 
Russell N, Cook G, Ascough P, Scott EM, Dugmore AJ. 2011. Examining the inherent variability in $\Delta \mathrm{R}$ : New methods of presenting $\Delta \mathrm{R}$ values and implications for MRE studies, Radiocarbon 53 (2):277-88.

Salmi A-K, Äikäs T, Fjellström M, Spangen M. 2015. Animal offerings at the Sámi offering site of Unna Saiva - Changing religious practices and humananimal relationships. Journal of Anthropological Archaeology 40:10-22.

Sayle KL, Cook GT, Ascough PL, Gestsdóttir H, Derek Hamilton W, McGovern TH. 2014. Utilization of $\delta^{13} \mathrm{C}, \delta^{15} \mathrm{~N}$, and $\delta^{34} \mathrm{~S}$ analyses to understand ${ }^{14} \mathrm{C}$ dating anomalies within a Late Viking Age community in northeast Iceland. Radiocarbon 56(2):811-21.
Sayle KL, Hamilton WD, Gestsdóttir H, Cook GT. 2016. Modelling Lake Mývatn's freshwater reservoir effect: Utilisation of the statistical program FRUITS to assist in the re-interpretation of radiocarbon dates from a cemetery at Hofstaðir, north-east Iceland. Quaternary Geochronology 36:1-11.

Vorren Ø, Manker EM. 1976. Samekulturen : en kulturhistorisk oversikt. Oslo: Universitetsforlaget.

Wallerström T. 2017. Kunglig makt och samiska bosättningsmönster: Studier kring Väinö Tanners vinterbyteori. Instituttet for sammenlignende kulturforskning. Serie B. Skrifter CLXV. Oslo: Novus forlag.

Wiklund KB. 1916. Rounala kyrka. Uppsala: Almqvist \& Wiksell. 
$1576 J$ P R Dury et al.

APPENDIX 1. LAB CODES AND ${ }^{14} \mathrm{C}$ AGES REPORTED FOR ROUNALA HUMAN SAMPLES.

\begin{tabular}{lllr}
\hline Rounala human & Lab code & ${ }^{14} \mathrm{C}$ age BP & \pm \\
\hline 1 & LuA-5023 & 580 & 85 \\
3 & Ua-39943 & 429 & 30 \\
4 & Ua-40582 & 414 & 30 \\
5 & Ua-40581 & 492 & 30 \\
6 & LuA-5041 & 595 & 90 \\
6 & LuA-5144 & 750 & 95 \\
7 & Ua-39944 & 371 & 31 \\
8 & Ua-39941 & 527 & 30 \\
9 & Ua-39945 & 460 & 30 \\
10 & LuA-5040 & 515 & 85 \\
10 & Ua-42006 & 467 & 30 \\
11 & Ua-40584 & 451 & 30 \\
12 & LuA-5039 & 395 & 100 \\
12 & Ua-42005 & 523 & 30 \\
13 & Ua-40585 & 513 & 30 \\
14 & Ua-40583 & 407 & 30 \\
16 & Ua-39947 & 270 & 30 \\
L17a & Ua-48690 & 457 & 32 \\
L17b & Ua-48691 & 550 & 32 \\
18 & Ua-39942 & 337 & 30 \\
20 & Ua-39946 & 552 & 30 \\
21 & Ua-39948 & 287 & 30 \\
\hline
\end{tabular}


APPENDIX 2. THE $\delta^{13} \mathrm{C}, \delta^{15} \mathrm{~N}$ AND $\delta^{34} \mathrm{~S}$ VALUES AND COLLAGEN QUALITY INDICATORS FOR THE ROUNALA HUMANS AND ANALYZED REINDEER AND FISH. SAMPLES AND $\delta^{13} \mathrm{C}$ VALUES MARKED WITH AN $\left(^{*}\right)$ HAVE BEEN ADJUSTED FOR THE SUESS EFFECT $\left(\delta^{13} \mathrm{C}+1.5 \%\right)$.

\begin{tabular}{|c|c|c|c|c|c|c|c|c|c|c|c|c|c|}
\hline Lab code & Species/individual & Site & Skeletal element & Collagen yield ( $\%)$ & $\delta^{13} \mathrm{C}(\% \circ)$ & $\delta^{15} \mathrm{~N}(\% \circ)$ & $\delta^{34} \mathrm{~S}(\% 0)$ & $\% \mathrm{C}$ & $\% \mathrm{~N}$ & $\% \mathrm{~S}$ & $\begin{array}{l}\mathrm{C}: \\
\mathrm{N}\end{array}$ & $\begin{array}{l}\mathrm{C}: \\
\mathrm{S}\end{array}$ & $\begin{array}{l}\mathrm{N}: \\
\mathrm{S}\end{array}$ \\
\hline ROU3A & Homo sapiens 1 & Rounala & Cranium & 7.0 & -17.9 & 11.3 & 10.7 & 43.5 & 15.7 & 0.19 & 3.2 & 611 & 189 \\
\hline ROU12A & Homo sapiens 3 & Rounala & Cranium & 6.3 & -18.5 & 12.5 & 10.0 & 43.2 & 15.4 & 0.21 & 3.3 & 548 & 167 \\
\hline ROU5A & Homo sapiens 4 & Rounala & Cranium & 7.0 & -17.1 & 14.0 & 12.0 & 42.0 & 15.4 & 0.22 & 3.2 & 513 & 160 \\
\hline ROU8A & Homo sapiens 5 & Rounala & Cranium & 5.1 & -18.1 & 12.7 & 9.3 & 43.6 & 15.8 & 0.21 & 3.2 & 553 & 172 \\
\hline ROU4A & Homo sapiens 6 & Rounala & Cranium & 3.6 & -18.4 & 12.3 & 11.5 & 40.3 & 14.0 & 0.22 & 3.4 & 488 & 146 \\
\hline ROU13A & Homo sapiens 7 & Rounala & Cranium & 3.4 & -18.0 & 12.3 & 11.7 & 42.3 & 15.3 & 0.23 & 3.2 & 491 & 152 \\
\hline ROU10A & Homo sapiens 8 & Rounala & Cranium & 5.7 & -18.4 & 11.9 & 8.5 & 42.6 & 15.6 & 0.21 & 3.2 & 540 & 170 \\
\hline ROU14A & Homo sapiens 9 & Rounala & Cranium & 3.2 & -18.0 & 13.6 & 10.4 & 43.2 & 15.8 & 0.25 & 3.2 & 461 & 144 \\
\hline ROU7A & Homo sapiens 10 & Rounala & Cranium & 4.3 & -17.9 & 12.6 & 10.3 & 43.3 & 15.8 & 0.22 & 3.2 & 524 & 164 \\
\hline ROU2A & Homo sapiens 11 & Rounala & Cranium & 5.5 & -17.5 & 11.8 & 10.6 & 43.4 & 15.7 & 0.22 & 3.2 & 526 & 163 \\
\hline ROU6A & Homo sapiens 12 & Rounala & Cranium & 2.4 & -17.7 & 11.6 & 11.2 & 42.2 & 15.5 & 0.24 & 3.2 & 469 & 148 \\
\hline ROU1A & Homo sapiens 13 & Rounala & Cranium & 5.1 & -18.0 & 12.0 & 10.0 & 44.0 & 15.8 & 0.22 & 3.2 & 533 & 164 \\
\hline ROU9A & Homo sapiens 14 & Rounala & Cranium & 5.8 & -18.5 & 10.5 & 11.3 & 43.5 & 15.9 & 0.2 & 3.2 & 579 & 181 \\
\hline ROU16A & Homo sapiens 16 & Rounala & Cranium & 3.2 & -18.7 & 10.2 & 11.9 & 42.6 & 15.5 & 0.22 & 3.2 & 516 & 161 \\
\hline ROU11A & Homo sapiens 18 & Rounala & Cranium & 3.2 & -18.2 & 11.7 & 11.3 & 43.7 & 15.8 & 0.23 & 3.2 & 506 & 157 \\
\hline ROU15A & Homo sapiens 20 & Rounala & Cranium & 3.0 & -18.1 & 14.2 & 9.5 & 43.3 & 16.0 & 0.23 & 3.2 & 503 & 159 \\
\hline ROU17A & Homo sapiens 21 & Rounala & Cranium & 4.6 & -18.0 & 11.8 & 12.0 & 43.2 & 15.8 & 0.21 & 3.2 & 549 & 172 \\
\hline ROU18 & Homo sapiens L17a & Rounala & Humerus & 4.5 & -17.2 & 14.8 & 7.7 & 35.2 & 12.8 & 0.13 & 3.2 & 723 & 225 \\
\hline ROU19 & Homo sapiens L17b & Rounala & Humerus & 6.0 & -18.3 & 10.9 & 9.3 & 41.1 & 15.2 & 0.14 & 3.2 & 782 & 248 \\
\hline KÖN 1* & Rangifer tarandus & Könkämä siida & Mandibula & 8.6 & $-18.5^{*}$ & 2.2 & 10.7 & 44.9 & 16.5 & 0.27 & 3.2 & 444 & 140 \\
\hline KÖN 2* & Rangifer tarandus & Könkämä siida & Mandibula & 9.1 & $-18.9 *$ & 2.1 & 9.3 & 43.4 & 15.0 & 0.30 & 3.4 & 446 & 132 \\
\hline KÖN 3* & Rangifer tarandus & Könkämä siida & Mandibula & 10.5 & $-19.5^{*}$ & 3.4 & 10.4 & 47.0 & 15.6 & 0.27 & 3.5 & 464 & 132 \\
\hline $\mathrm{KÖN} 4 *$ & Rangifer tarandus & Könkämä siida & Mandibula & 12.2 & $-19.0 *$ & 3.0 & 11.5 & 45.6 & 16.0 & 0.25 & 3.3 & 487 & 146 \\
\hline KÖN 5* & Rangifer tarandus & Könkämä siida & Mandibula & 9.8 & $-18.8 *$ & 2.4 & 10.1 & 44.9 & 15.7 & 0.28 & 3.3 & 428 & 128 \\
\hline LEP 1 & Rangifer tarandus & $\begin{array}{l}\text { Leppäkoski } \\
\text { hytta }\end{array}$ & Ulna & 9.1 & -19.8 & 3.1 & 8.6 & 42.5 & 15.3 & 0.20 & 3.2 & 567 & 175 \\
\hline LEP 2 & Rangifer tarandus & $\begin{array}{l}\text { Leppäkoski } \\
\text { hytta }\end{array}$ & Vertebra & 3.2 & -20.2 & 2.3 & 12.8 & 41.3 & 15.0 & 0.19 & 3.2 & 580 & 181 \\
\hline LEP 3 & Rangifer tarandus & & Scapula & 10.1 & -19.5 & 2.8 & 7.9 & 42.0 & 15.3 & 0.20 & 3.2 & 561 & 175 \\
\hline
\end{tabular}


Lab code Species/individual Site

Leppäkoski hytta

NMS 6 Rangifer tarandus Vallevare

NMS 10 Rangifer tarandus Unna Paddus

NMS 11 Rangifer tarandus Unna Paddus

NMS 12 Rangifer tarandus Unna Paddus

NMS 13 Rangifer tarandus

RAU 7 Rangifer tarandus

FB1* Salmo salar

FB2* Salmo salar

FB3* Salmo salar

FM1* Salmo salar

FM2* Salmo salar

FM3* Salmo salar

REB 5* Salmo trutta

REB $1 * \quad$ Salvelinus alpinus

REB 2* Salvelinus alpinus

REB 3* Salvelinus alpinus

LAI 2* Salvelinus alpinus

Unna Paddus

Rautasjaure

Målselva

Målselva

Målselva

Målselva

Målselva

Målselva

Riebnesjaure

Riebnesjaure

Riebnesjaure

Riebnesjaure

Laisälven $\begin{array}{lllllllllllll} & \text { C: } & C: & N \\ \text { Skeletal element Collagen yield }(\%) & \delta^{13} \mathrm{C}(\% \circ) & \delta^{15} \mathrm{~N}(\% \circ) & \delta^{34} \mathrm{~S}(\% \circ) & \% \mathrm{C} & \% \mathrm{~N} & \% \mathrm{~S} & \mathrm{~N} & \mathrm{~S} & \mathrm{~S}\end{array}$

$\begin{array}{ll}\text { Mandibula } & 3.6 \\ \text { Mandibula } & 4.1 \\ \text { Mandibula } & 1.3 \\ \text { Mandibula } & 3.5 \\ \text { Mandibula } & 4.3 \\ \text { Tibia } & 3.5 \\ \text { vertebra } & 3.7 \\ \text { vertebra } & 5.9 \\ \text { vertebra } & 3.0 \\ \text { Muscle } & - \\ \text { Muscle } & - \\ \text { Muscle } & - \\ \text { vertebra } & 6.3 \\ \text { vertebra } & 2.3 \\ \text { vertebra } & 3.9 \\ \text { vertebra } & 8.5 \\ \text { vertebra } & 8.4\end{array}$

$\begin{array}{lrl}-19.1 & 2.3 & - \\ -21.9 & 5.9 & - \\ -21.9 & 4.7 & - \\ -21.6 & 3.2 & - \\ -21.7 & 4.3 & - \\ -18.9 & 2.0 & 11.6 \\ -16.7 * & 12.4 & 18.3 \\ -16.1^{*} & 12.3 & 17.4 \\ -18.0^{*} & 10.1 & 18.2 \\ -18.4^{*} & 13.7 & 18.4 \\ -18.3^{*} & 13.7 & 18.4 \\ -19.1 * & 11.4 & 16.7 \\ -21.6 & 7.0 & 9.2 \\ - & - & 8.7 \\ -22.5 & 6.0 & 8.9 \\ -22.6 & 5.8 & 9.2 \\ -19.0 & 6.9 & 8.2\end{array}$

$41.014 .4-3.3-3.3-$

$41.414 .5-3.3-3.5-$

$34.811 .7-3.5--$

$42.014 .9-3.3--$

$41.114 .7-3.3--$

$\begin{array}{llllll}35.1 & 13.3 & 0.23 & 3.1 & 408 & 132\end{array}$

$\begin{array}{llllll}41.8 & 13.8 & 1.07 & 3.5 & 104 & 29\end{array}$

$\begin{array}{llllll}49.0 & 16.8 & 1.00 & 3.4 & 131 & 38\end{array}$

$\begin{array}{llllll}42.0 & 13.3 & 1.25 & 3.7 & 89 & 24\end{array}$

$\begin{array}{lllllll}48.7 & 15.5 & 1.14 & 3.7 & 114 & 31\end{array}$

$\begin{array}{llllll}48.6 & 15.4 & 1.21 & 3.7 & 107 & 29\end{array}$

$\begin{array}{llllll}48.8 & 15.6 & 1.24 & 3.7 & 105 & 29\end{array}$

$\begin{array}{llllll}44.9 & 17.2 & 0.50 & 3.1 & 240 & 79\end{array}$

$\begin{array}{llllll}- & - & 0.53 & - & - & -\end{array}$

$\begin{array}{lllllll}44.9 & 16.7 & 0.51 & 3.1 & 235 & 75\end{array}$

$\begin{array}{llllll}44.8 & 17.0 & 0.51 & 3.1 & 235 & 76\end{array}$ 


\begin{abstract}
APPENDIX 3. THE $\delta^{13} \mathrm{C}, \delta^{15} \mathrm{~N}$ AND $\delta^{34} S$ VALUES OF FAUNAL SAMPLES USED FOR FRUITS MODELING. SAMPLES MARKED WITH AN $\left(^{*}\right)$ HAVE $\delta^{13} \mathrm{C}$ VALUES ADJUSTED FOR THE SUESS EFFECT.
\end{abstract}

\begin{tabular}{|c|c|c|c|c|c|c|}
\hline Species & $\begin{array}{l}\text { Common } \\
\text { name }\end{array}$ & Site & $\begin{array}{l}\delta^{13} \mathrm{C} \\
(\% o)\end{array}$ & $\begin{array}{l}\delta^{15} \mathrm{~N} \\
(\% 0)\end{array}$ & $\begin{array}{l}\delta^{34} S \\
(\% o)\end{array}$ & Publication \\
\hline \multicolumn{7}{|l|}{ Atlantic cod } \\
\hline Gadus morhua & Atlantic cod & Helgøygården & -16.0 & 13.9 & - & Barrett et al. 2011 \\
\hline Gadus morhua & Atlantic cod & Helgøygården & -15.5 & 12.8 & - & Barrett et al. 2011 \\
\hline Gadus morhua & Atlantic cod & Helgøygården & -12.4 & 14.4 & - & Barrett et al. 2011 \\
\hline Gadus morhua & Atlantic cod & Helgøygården & -13.7 & 14.3 & - & Barrett et al. 2011 \\
\hline Gadus morhua & Atlantic cod & Helgøygården & -14.6 & 14.6 & - & Barrett et al. 2011 \\
\hline Gadus morhua & Atlantic cod & Helgøygården & -13.5 & 14.4 & - & Barrett et al. 2011 \\
\hline Gadus morhua & Atlantic cod & Kongshavn & -15.4 & 13.8 & - & Barrett et al. 2011 \\
\hline Gadus morhua & Atlantic cod & Kongshavn & -15.3 & 14.8 & - & Barrett et al. 2011 \\
\hline Gadus morhua & Atlantic cod & Kongshavn & -14.4 & 13.8 & - & Barrett et al. 2011 \\
\hline Gadus morhua & Atlantic cod & Kongshavn & -17.1 & 13.2 & - & Barrett et al. 2011 \\
\hline Gadus morhua & Atlantic cod & Kongshavn & -15.9 & 13.7 & - & Barrett et al. 2011 \\
\hline Gadus morhua & Atlantic cod & Måsøy & -14.8 & 13.9 & - & Barrett et al. 2011 \\
\hline Gadus morhua & Atlantic cod & Mås & -14.2 & 14.1 & - & Barrett et al. 2011 \\
\hline Gadus morhua & Atlantic cod & Mås & -14.7 & 14.4 & - & Barrett et al. 2011 \\
\hline Gadus morhua & Atlantic cod & Måsøy & -14.7 & 14.8 & - & Barrett et al. 2011 \\
\hline Gadus morhua & Atlantic cod & Måsøy & -13.6 & 13.8 & - & Barrett et al. 2011 \\
\hline Gadus morhua & Atlantic cod & Måsøy & -15.3 & 13.6 & - & Barrett et al. 2011 \\
\hline Gadus morhua & Atlantic cod & Måsøy & -14.8 & 13.8 & - & Barrett et al. 2011 \\
\hline Gadus morhua & Atlantic cod & Må & -15.2 & 12.6 & - & Barrett et al. 2011 \\
\hline Gadus morhua & $\operatorname{cod}$ & Må & -14.7 & & - & 011 \\
\hline Gadus morhua & Atlantic cod & Måsøy & -13.1 & 14.7 & - & Barrett et al. 2011 \\
\hline Gadus morhua & Atlantic cod & Skonsvika & -13.7 & 14.3 & - & Barrett et al. 2011 \\
\hline Gadus morhua & Atlantic cod & Skonsvika & -14.8 & 14.2 & - & Barrett et al. 2011 \\
\hline Gadus morhua & Atlantic cod & Skonsvika & -14.0 & 15.7 & - & Barrett et al. 2011 \\
\hline Gadus morhua & Atlantic cod & & -14.4 & 13.6 & - & Barrett et al. 2011 \\
\hline Gadus morhua & Atlan & Stor & -14.8 & & - & et al. 2011 \\
\hline Gadus morhua & Atlantic cod & Storvågan & -15.6 & 14.2 & - & Barrett et al. 2011 \\
\hline Gadus morhua & Atlantic cod & Storvågan & -13.9 & 14.3 & - & Barrett et al. 2011 \\
\hline Gadus morhua & Atlantic cod & Storvågan & -13.6 & 15.8 & - & Barrett et al. 2011 \\
\hline Gadus morhua & Atlantic cod & Vannareid & -14.9 & 13.9 & - & Barrett et al. 2011 \\
\hline Gadus morhua & Atlantic cod & Van & -15.4 & 14.2 & - & Barrett et al. 2011 \\
\hline Gadus morhua & Atlantic cod & Vannareid & -13.9 & 15.0 & - & Barrett et al. 2011 \\
\hline Gadus morhua & Atlantic cod & Vannareid & -13.8 & 15.3 & - & Barrett et al. 2011 \\
\hline Gadus morhua & Atlantic cod & Vannareid & -15.1 & 14.0 & - & Barrett et al. 2011 \\
\hline Gadus morhua & Atlantic cod & Vannareid & -14.4 & 13.1 & - & Barrett et al. 2011 \\
\hline Gadus morhua & Atlantic cod & Vannareid & -14.6 & 14.4 & - & Barrett et al. 2011 \\
\hline Gadus morhua & Atlantic cod & Van & -15.4 & 15.6 & - & Barrett et al. 2011 \\
\hline Gadus morhua & Atlantic cod & Vannareid & -14.7 & 14.9 & - & Barrett et al. 2011 \\
\hline Gadus morhua & Atlantic cod & Vannareid & -14.6 & 14.6 & - & Barrett et al. 2011 \\
\hline Gadus morhua & Atlantic cod & Vannareid & -13.7 & 13.4 & - & Barrett et al. 2011 \\
\hline Gadus morhua & Atlantic cod & Vannareid & -15.0 & 14.1 & - & Barrett et al. 2011 \\
\hline Gadus morhua & Atlantic cod & Alstahaug & - & - & 16.5 & Nehlich et al. 2013 \\
\hline
\end{tabular}


APPENDIX 3. Continued

\begin{tabular}{|c|c|c|c|c|c|c|}
\hline Species & $\begin{array}{l}\text { Common } \\
\text { name }\end{array}$ & Site & $\begin{array}{l}\delta^{13} \mathrm{C} \\
(\% o)\end{array}$ & $\begin{array}{l}\delta^{15} \mathrm{~N} \\
(\% 0)\end{array}$ & $\begin{array}{l}\delta^{34} \mathrm{~S} \\
(\% \circ)\end{array}$ & Publication \\
\hline Gadus morhua & Atlantic cod & Alstahaug & - & - & 14.6 & Nehlich et al. 2013 \\
\hline Gadus morhua & Atlantic cod & Alstahaug & - & - & 15.5 & Nehlich et al. 2013 \\
\hline Gadus morhua & Atlantic cod & Alstahaug & - & - & 16.2 & Nehlich et al. 2013 \\
\hline Gadus morhua & Atlantic cod & Alstahaug & - & - & 15.3 & Nehlich et al. 2013 \\
\hline Gadus morhua & Atlantic cod & Helgøygården & - & - & 15.7 & Nehlich et al. 2013 \\
\hline Gadus morhua & Atlantic cod & Helgøygården & - & - & 15.5 & Nehlich et al. 2013 \\
\hline Gadus morhua & Atlantic cod & Helgøygården & - & - & 16.4 & Nehlich et al. 2013 \\
\hline Gadus morhua & Atlantic cod & Storvågan & - & - & 16.0 & Nehlich et al. 2013 \\
\hline Gadus morhua & Atlantic cod & Storvågan & - & - & 16.9 & Nehlich et al. 2013 \\
\hline \multicolumn{7}{|l|}{ Reindeer } \\
\hline $\begin{array}{l}\text { Rangifer } \\
\text { tarandus * }\end{array}$ & Reindeer & $\begin{array}{l}\text { Könkämä } \\
\text { siida }\end{array}$ & -18.5 & 2.2 & 10.7 & This study \\
\hline $\begin{array}{l}\text { Rangifer } \\
\text { tarandus } *\end{array}$ & Reindeer & $\begin{array}{l}\text { Könkämä } \\
\text { siida }\end{array}$ & -18.9 & 2.1 & 9.3 & This study \\
\hline $\begin{array}{l}\text { Rangifer } \\
\text { tarandus } *\end{array}$ & Reindeer & $\begin{array}{l}\text { Könkämä } \\
\text { siida }\end{array}$ & -19.5 & 3.4 & 10.4 & This study \\
\hline $\begin{array}{l}\text { Rangifer } \\
\text { tarandus } *\end{array}$ & Reindeer & $\begin{array}{l}\text { Könkämä } \\
\text { siida }\end{array}$ & -19.0 & 3.0 & 11.5 & This study \\
\hline $\begin{array}{l}\text { Rangifer } \\
\text { tarandus } *\end{array}$ & Reindeer & $\begin{array}{l}\text { Könkämä } \\
\text { siida }\end{array}$ & -18.8 & 2.4 & 10.1 & This study \\
\hline $\begin{array}{l}\text { Rangifer } \\
\text { tarandus }\end{array}$ & Reindeer & $\begin{array}{l}\text { Leppäkoski } \\
\text { hytta }\end{array}$ & -19.8 & 3.1 & 8.6 & This study \\
\hline $\begin{array}{l}\text { Rangifer } \\
\text { tarandus }\end{array}$ & Reindeer & $\begin{array}{l}\text { Leppäkoski } \\
\text { hytta }\end{array}$ & -20.2 & 2.3 & 12.8 & This study \\
\hline $\begin{array}{l}\text { Rangifer } \\
\text { tarandus }\end{array}$ & Reindeer & $\begin{array}{l}\text { Leppäkoski } \\
\text { hytta }\end{array}$ & -19.5 & 2.8 & 7.9 & This study \\
\hline $\begin{array}{l}\text { Rangifer } \\
\text { tarandus }\end{array}$ & Reindeer & Rautasjaure & -18.9 & 2.0 & 11.6 & This study \\
\hline $\begin{array}{l}\text { Rangifer } \\
\text { tarandus }\end{array}$ & Reindeer & Vallevare & -19.1 & 2.3 & - & This study \\
\hline $\begin{array}{l}\text { Rangifer } \\
\text { tarandus }\end{array}$ & Reindeer & Unna Paddus & -21.9 & 5.9 & - & This study \\
\hline $\begin{array}{l}\text { Rangifer } \\
\text { tarandus }\end{array}$ & Reindeer & Unna Paddus & -21.9 & 4.7 & - & This study \\
\hline $\begin{array}{l}\text { Rangifer } \\
\text { tarandus }\end{array}$ & Reindeer & Unna Paddus & -21.6 & 3.2 & - & This study \\
\hline $\begin{array}{l}\text { Rangifer } \\
\text { tarandus }\end{array}$ & Reindeer & Unna Paddus & -21.7 & 4.3 & - & This study \\
\hline \multicolumn{7}{|l|}{ Freshwater fish } \\
\hline $\begin{array}{c}\text { Salvelinus } \\
\text { alpinus * }\end{array}$ & Arctic char & Riebnesjaure & -22.5 & 6.0 & 8.9 & This study \\
\hline $\begin{array}{l}\text { Salvelinus } \\
\text { alpinus * }\end{array}$ & Arctic char & Riebnesjaure & - & - & 8.7 & This study \\
\hline $\begin{array}{l}\text { Salvelinus } \\
\text { alpinus * }\end{array}$ & Arctic char & Riebnesjaure & -22.6 & 5.8 & 9.2 & This study \\
\hline
\end{tabular}


APPENDIX 3. Continued

\begin{tabular}{|c|c|c|c|c|c|c|}
\hline Species & $\begin{array}{l}\text { Common } \\
\text { name }\end{array}$ & Site & $\begin{array}{l}\delta^{13} \mathrm{C} \\
(\% o)\end{array}$ & $\begin{array}{l}\delta^{15} \mathrm{~N} \\
(\% 0)\end{array}$ & $\begin{array}{l}\delta^{34} \mathrm{~S} \\
(\% \circ)\end{array}$ & Publication \\
\hline $\begin{array}{c}\text { Salvelinus } \\
\text { alpinus * }\end{array}$ & Arctic char & Laisälven & -19.0 & 6.9 & 8.2 & This study \\
\hline Salmo trutta * & Brown trout & Riebnesjaure & -21.6 & 7.0 & 9.2 & This study \\
\hline \multicolumn{7}{|l|}{ Atlantic salmon } \\
\hline Salmo salar * & $\begin{array}{r}\text { Atlantic } \\
\text { salmon }\end{array}$ & Målselva & -16.7 & 12.4 & 18.3 & This study \\
\hline Salmo salar * & $\begin{array}{r}\text { Atlantic } \\
\text { salmon }\end{array}$ & Målselva & -16.1 & 12.3 & 17.4 & This study \\
\hline Salmo salar * & $\begin{array}{l}\text { Atlantic } \\
\text { salmon }\end{array}$ & Målselva & -18.0 & 10.1 & 18.2 & This study \\
\hline
\end{tabular}


APPENDIX 4. OXCAL MODEL CODE

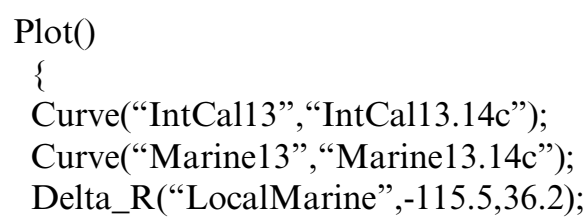

Mix_Curve("Mixed", "IntCal13",

"LocalMarine", 41.8,19.5);

R_Date("Mixed Marine 6", 669, 65) \& Date (U(0,1800));

Curve("IntCal13", "IntCal13.14c");

Curve("Marine13","Marine13.14c");

Delta_R(“LocalMarine”,-189,4);

Mix_Curve("Mixed", "IntCal13",

"LocalMarine", 28.7,16.1);

R_Date("Baltic Marine 6", 670, 65)\& Date (U(0,1800));

Curve("IntCal13", "IntCal13.14c");

Curve("Marine13", "Marine13.14c");

Delta_R("LocalMarine",-126.0,36.2);

Mix_Curve("Mixed", "IntCal13",

"LocalMarine", 22.0,14.0);

R_Date("Mixed Marine L17b", 550, 32) \& Date(U(0,1800));

Curve("IntCal13", "IntCal13.14c");

Curve("Marine13","Marine13.14c");

Delta_R(“LocalMarine",-189,4);

Mix_Curve("Mixed", "IntCal13",

"LocalMarine", 14.5,11.3);

R_Date("Baltic Marine L17b", 550, 32) \& Date(U(0,1800));

Curve("IntCal13", "IntCal13.14c");

Curve("Marine13", "Marine13.14c");

Delta_R("LocalMarine",-107.8,36.2);

Mix_Curve("Mixed", "IntCal13",

"LocalMarine",32.7,15.1);

R_Date("Mixed Marine 1", 580,85) \& Date (U(0,1800));

Curve("IntCal13", "IntCal13.14c");

Curve("Marine13","Marine13.14c");

Delta_R("LocalMarine",-189,4);

Mix_Curve("Mixed", "IntCal13",

"LocalMarine",22.2,14.3);
R_Date("Baltic Marine 1", 580,85)\& Date (U(0,1800));

Curve("IntCal13","IntCal13.14c");

Curve("Marine13","Marine13.14c");

Delta_R(“LocalMarine",-136.8,36.2);

Mix_Curve("Mixed", "IntCal13",

"LocalMarine", 19.4,12.6);

R_Date("Mixed Marine 8", 527, 30) \& Date (U(0,1800));

Curve("IntCal13","IntCal13.14c");

Curve("Marine13","Marine13.14c");

Delta_R(“LocalMarine”,-189,4);

Mix_Curve("Mixed", "IntCal13",

"LocalMarine", 16.1,14.7);

R_Date("Baltic Marine 8", 527, 30)\& Date (U(0,1800));

Curve("IntCal13","IntCal13.14c");

Curve("Marine13","Marine13.14c");

Delta_R("LocalMarine",-118.4,36.2);

Mix_Curve("Mixed", "IntCal13”,

"LocalMarine",30.0,15.8);

R_Date("Mixed Marine 13", 513, 30) \& Date(U(0,1800));

Curve("IntCal13", "IntCal13.14c");

Curve("Marine13","Marine13.14c");

Delta_R(“LocalMarine”,-189,4);

Mix_Curve("Mixed" "IntCal13",

"LocalMarine", 25.1,15.7);

R_Date("Baltic Marine 13", 513, 30)\& Date (U(0,1800));

Curve("IntCal13","IntCal13.14c");

Curve("Marine13","Marine13.14c");

Delta_R("LocalMarine",-150.4,36.2);

Mix_Curve("Mixed", "IntCal13",

"LocalMarine",41.7,19.5);

R_Date("Mixed Marine 20", 552, 30) \& Date(U(0,1800));

Curve("IntCal13", "IntCal13.14c");

Curve("Marine13","Marine13.14c");

Delta_R("LocalMarine",-189,4);

Mix_Curve("Mixed", "IntCal13",

"LocalMarine",41.1,15.8); 
R_Date("Baltic Marine 20", 552, 30)\& Date (U(0,1800));

Curve("IntCal13”, "IntCal13.14c");

Curve("Marine13","Marine13.14c");

Delta_R(“LocalMarine”,-105.1,36.2);

Mix_Curve("Mixed", "IntCal13",

"LocalMarine", 38.4,18.8);

R_Date(“Mixed Marine 12", 513, 29) \& Date (U(0,1800));

Curve("IntCal13”,"IntCal13.14c");

Curve("Marine13", "Marine13.14c");

Delta_R("LocalMarine",-189,4);

Mix_Curve("Mixed", "IntCal13",

"LocalMarine", 24.5, 15.0);

R_Date("Baltic Marine 12”, 513, 29)\& Date (U(0,1800));

Curve("IntCal13","IntCal13.14c");

Curve("Marine13", "Marine13.14c");

Delta_R(“LocalMarine”,-138.2,36.2);

Mix_Curve("Mixed", "IntCal13",

"LocalMarine", 29.5,15.2);

R_Date("Mixed Marine 5", 492, 30) \& Date (U(0,1800));

Curve("IntCal13", "IntCal13.14c");

Curve("Marine13", "Marine13.14c");

Delta_R("LocalMarine",-189,4);

Mix_Curve("Mixed","IntCal13",

"LocalMarine", 27.2,16.9);

R_Date("Baltic Marine 5", 492, 30)\& Date (U(0,1800));

Curve("IntCa113", "IntCal13.14c");

Curve("Marine13","Marine13.14c");

Delta_R(“LocalMarine”,-124.3,36.2);

Mix_Curve("Mixed", "IntCal13",

"LocalMarine",38.1,19.7);

R_Date(“Mixed Marine 10", 472, 28) \& Date (U(0,1800));

Curve("IntCal13","IntCal13.14c");

Curve("Marine13","Marine13.14c");

Delta_R("LocalMarine",-189,4);

Mix_Curve("Mixed", "IntCal13",

"LocalMarine", 26.8,14.2);
R_Date("Baltic Marine 10", 472, 28)\& Date

(U(0,1800));

Curve("IntCal13", "IntCal13.14c");

Curve("Marine13","Marine13.14c");

Delta_R(“LocalMarine”,-112.5,36.2);

Mix_Curve("Mixed", "IntCal13",

"LocalMarine", 36.5,18.2);

R_Date("Mixed Marine 11", 451, 30) \& Date (U(0,1800));

Curve("IntCal13", "IntCal13.14c");

Curve("Marine13","Marine13.14c");

Delta_R(“LocalMarine",-189,4);

Mix_Curve("Mixed", "IntCal13",

"LocalMarine", 20.3,12.9);

R_Date("Baltic Marine 11", 451, 30)\& Date (U(0,1800));

Curve("IntCal13","IntCal13.14c");

Curve("Marine13", "Marine13.14c");

Delta_R(“LocalMarine”,-131.2,36.2);

Mix_Curve("Mixed", "IntCal13",

"LocalMarine", 32.5,17.0);

R_Date("Mixed Marine 3", 429, 30) \& Date (U(0,1800));

Curve("IntCal13", "IntCal13.14c");

Curve("Marine13","Marine13.14c");

Delta_R(“LocalMarine",-189,4);

Mix_Curve("Mixed" "IntCal13",

"LocalMarine", 26.6,15.4);

R_Date("Baltic Marine 3", 429, 30)\& Date

(U(0,1800));

Curve("IntCa113", "IntCal13.14c");

Curve("Marine13","Marine13.14c");

Delta_R(“LocalMarine”,-112.9,36.2);

Mix_Curve("Mixed", "IntCal13",

"LocalMarine",31.4,16.5);

R_Date("Mixed Marine 14", 407, 30) \& Date (U(0,1800));

Curve("IntCa113","IntCal13.14c");

Curve("Marine13", "Marine13.14c");

Delta_R(“LocalMarine",-189,4);

Mix_Curve("Mixed", "IntCal13",

"LocalMarine", 18.7,13.4); 
R_Date("Baltic Marine 14", 407, 30)\& Date (U(0,1800));

Curve("IntCal13", "IntCal13.14c");

Curve("Marine13","Marine13.14c");

Delta_R(“LocalMarine”,-132.2,36.2);

Mix_Curve("Mixed", "IntCal13",

"LocalMarine",42.8,20.0);

R_Date("Mixed Marine 9", 460, 30) \& Date (U(0,1800));

Curve("IntCal13", "IntCal13.14c");

Curve("Marine13", "Marine13.14c");

Delta_R(“LocalMarine",-189,4);

Mix_Curve("Mixed", "IntCal13",

"LocalMarine",43.3,17.1);

R_Date("Baltic Marine 9", 460, 30) \& Date (U(0,1800));

Curve("IntCal13", "IntCal13.14c");

Curve("Marine13", "Marine13.14c");

Delta_R(“LocalMarine”,-170.2,36.2);

Mix_Curve("Mixed", "IntCal13",

"LocalMarine", 53.1,21.8);

R_Date("Mixed Marine L17a", 457, 32) \& Date(U(0,1800));

Curve("IntCal13", "IntCal13.14c");

Curve("Marine13", "Marine13.14c");

Delta_R("LocalMarine",-189,4);

Mix_Curve("Mixed", "IntCal13",

"LocalMarine", 57.5,19.5);

R_Date("Baltic Marine L17a", 457, 32) \& Date(U(0,1800));

Curve("IntCal13", "IntCal13.14c");

Curve("Marine13","Marine13.14c");

Delta_R(“LocalMarine”,-109.9,36.2);

Mix_Curve("Mixed", "IntCal13",

"LocalMarine",42.6,19.3);

R_Date("Mixed Marine 7", 371, 31) \& Date (U(0,1800));

Curve("IntCal13", "IntCal13.14c");

Curve("Marine13","Marine13.14c");

Delta_R("LocalMarine",-189,4);

Mix_Curve("Mixed", "IntCal13",

"LocalMarine", 27.0,16.5);

R_Date("Baltic Marine 7", 371, 31)\& Date (U(0,1800));
Curve("IntCal13","IntCal13.14c");

Curve("Marine13", "Marine13.14c");

Delta_R(“LocalMarine”,-97.5,36.2);

Mix_Curve("Mixed",

"IntCal13",

"LocalMarine", 56.5,22.8);

R_Date("Mixed Marine 4", 414, 30) \& Date (U(0,1800));

Curve("IntCal13","IntCal13.14c");

Curve("Marine13", "Marine13.14c");

Delta_R(“LocalMarine",-189,4);

Mix_Curve("Mixed", "IntCal13",

"LocalMarine",45.1,19.4);

R_Date("Baltic Marine 4", 414, 30)\& Date

(U(0,1800));

Curve("IntCa113", "IntCal13.14c");

Curve("Marine13","Marine13.14c");

Delta_R(“LocalMarine”,-100.8,36.2);

Mix_Curve("Mixed", "IntCal13",

"LocalMarine",35.4,16.1);

R_Date("Mixed Marine 18", 337, 30) \& Date(U(0,1800));

Curve("IntCal13", "IntCal13.14c");

Curve("Marine13", "Marine13.14c");

Delta_R(“LocalMarine”,-189,4);

Mix_Curve("Mixed", "IntCal13”,

"LocalMarine", 29.7,17.7);

R_Date("Baltic Marine 18", 337, 30)\& Date

(U(0,1800));

Curve("IntCal13", "IntCal13.14c");

Curve("Marine13","Marine13.14c");

Delta_R("LocalMarine",-98.1,36.2);

Mix_Curve("Mixed", "IntCal13",

"LocalMarine",41.3,18.4);

R_Date("Mixed Marine 21", 287, 30) \& Date(U(0,1800));

Curve("IntCal13", "IntCal13.14c");

Curve("Marine13","Marine13.14c");

Delta_R(“LocalMarine",-189,4);

Mix_Curve("Mixed", "IntCal13”,

"LocalMarine", 28.0,17.7);

R_Date("Baltic Marine 21", 287, 30)\& Date

(U(0,1800));

Curve("IntCal13”, "IntCal13.14c”); 
Curve("Marine13", "Marine13.14c");

Delta_R(“LocalMarine”,-115.7,36.2);

Mix_Curve("Mixed", "IntCal13",

"LocalMarine", 32.5,16.0);

R_Date("Mixed Marine 16", 270, 30) \& Date(U(0,1800));

Curve(“IntCal13”,"IntCal13.14c”);
Curve("Marine13", "Marine13.14c");

Delta_R(“LocalMarine",-189,4);

Mix_Curve("Mixed","IntCa113",

"LocalMarine", 17.9,13.6);

R_Date("Baltic Marine 16", 270, 30)\& Date (U(0,1800)); 